\title{
BMJ Open Glucose intolerance associated with hypoxia in people living at high altitudes in the Tibetan highland
}

Kiyohito Okumiya, ${ }^{1,2}$ Ryota Sakamoto, ${ }^{2,3}$ Yasuko Ishimoto, ${ }^{4}$ Yumi Kimura, ${ }^{2}$ Eriko Fukutomi, ${ }^{2}$ Motonao Ishikawa, ${ }^{5}$ Kuniaki Suwa, ${ }^{5}$ Hissei Imai, ${ }^{6}$ Wenling Chen, ${ }^{2}$ Emiko Kato, ${ }^{2}$ Masahiro Nakatsuka, ${ }^{7}$ Yoriko Kasahara, ${ }^{8}$ Michiko Fujisawa, ${ }^{2}$ Taizo Wada, ${ }^{2}$ Hongxin Wang, ${ }^{9}$ Qingxiang Dai, ${ }^{9}$ Huining $\mathrm{Xu},{ }^{9}$ Haisheng Qiao, ${ }^{10}$ Ri-Li Ge, ${ }^{11}$ Tsering Norboo, ${ }^{12}$ Norboo Tsering, ${ }^{12}$ Yasuyuki Kosaka, ${ }^{13}$ Mitsuhiro Nose, ${ }^{2}$ Takayoshi Yamaguchi, ${ }^{14}$ Toshihiro Tsukihara, ${ }^{15}$ Kazuo Ando, ${ }^{2}$ Tetsuya Inamura, ${ }^{16}$ Shinya Takeda, ${ }^{13}$ Masayuki Ishine, ${ }^{17}$ Kuniaki Otsuka, ${ }^{5,18}$ Kozo Matsubayashi ${ }^{2}$

To cite: Okumiya $\mathrm{K}$, Sakamoto R, Ishimoto $\mathrm{Y}$, et al. Glucose intolerance associated with hypoxia in people living at high altitudes in the Tibetan highland. BMJ Open 2016;6:e009728. doi:10.1136/bmjopen-2015009728

- Prepublication history and additional material is available. To view please visit the journal (http://dx.doi.org/ 10.1136/bmjopen-2015009728).

Received 17 August 2015 Revised 3 November 2015 Accepted 3 December 2015

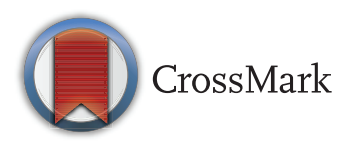

For numbered affiliations see end of article.

Correspondence to Dr Kiyohito Okumiya; okumiyak@hotmail.com

\section{ABSTRACT}

Objectives: To clarify the association between glucose intolerance and high altitudes (2900-4800 m) in a hypoxic environment in Tibetan highlanders and to verify the hypothesis that high altitude dwelling increases vulnerability to diabetes mellitus (DM) accelerated by lifestyle change or ageing.

Design: Cross-sectional epidemiological study on Tibetan highlanders.

Participants: We enrolled 1258 participants aged 4087 years. The rural population comprised farmers in Domkhar (altitude 2900-3800 m) and nomads in Haiyan (3000-3100 m), Ryuho (4400 m) and Changthang $(4300-4800 \mathrm{~m})$. Urban area participants were from Leh $(3300 \mathrm{~m})$ and Jiegu $(3700 \mathrm{~m})$.

Main outcome measure: Participants were classified into six glucose tolerance-based groups: DM, intermediate hyperglycaemia $(\mathrm{IHG})$, normoglycaemia $(N G)$, fasting $D M$, fasting $I H G$ and fasting NG. Prevalence of glucose intolerance was compared in farmers, nomads and urban dwellers. Effects of dwelling at high altitude or hypoxia on glucose intolerance were analysed with the confounding factors of age, sex, obesity, lipids, haemoglobin, hypertension and lifestyle, using multiple logistic regression.

Results: The prevalence of DM (fasting DM)/IHG (fasting $\mathrm{IHG}$ ) was $8.9 \%(6.5 \%) / 25.1 \%(12.7 \%)$, respectively, in all participants. This prevalence was higher in urban dwellers $(9.5 \%(7.1 \%) / 28.5 \%$ $(11.7 \%))$ and in farmers $(8.5 \%(6.1 \%) / 28.5 \%$ $(18.3 \%))$ compared with nomads $(8.2 \%(5.7 \%) / 15.7 \%$ $(9.7 \%))(p=0.0140 / 0.0001)$. Dwelling at high altitude was significantly associated with fasting $\mathrm{IHG}+$ fasting DM/fasting DM (ORs for $>4500$ and $3500-4499 \mathrm{~m}$ were $3.59 / 4.36$ and $2.07 / 1.76$ vs $<3500 \mathrm{~m}$, respectively). After adjusting for lifestyle change, hypoxaemia and polycythaemia were closely associated with glucose intolerance.

Conclusions: Socioeconomic factors, hypoxaemia and the effects of altitudes $>3500 \mathrm{~m}$ play a major role in the high prevalence of glucose intolerance in

\section{Strengths and limitations of this study}

- The study showed the first evidence of a close association of glucose intolerance with dwelling at high altitude over $3500 \mathrm{~m}$ or hypoxaemia after adjustment of lifestyle-related factors

- The study also showed the vulnerability of glucose intolerance in high-altitude people with adaptation to hypoxia accelerated by ageing and lifestyle change. In addition, this study used validated POC (point-of-care) analysers for blood glucose and haemoglobin measurement that were not affected by the high-altitude environment.

- Farmers and nomads could be analysed in different altitudes as almost homogeneous subjects. But urban dwellers, who had changed to a modernised lifestyle, were analysed at different altitudes, which was not homogeneous. Multiple logistic regression analysis was used for adjusting lifestyle and other confounding factors.

- It is a cross-sectional study and, thus, requires a future longitudinal study to disclose any causal relations. Also, the genes involved in adaptation to hypoxia were not examined. The study did not investigate whether nutrition and physical activities were confounding factors to glucose intolerance, but measuring body mass index and dyslipidaemia may reflect those effects.

highlanders. Tibetan highlanders may be vulnerable to glucose intolerance, with polycythaemia as a sign of poor hypoxic adaptation, accelerated by lifestyle change and ageing.

\section{INTRODUCTION}

Over many generations, people living at high altitudes have developed unique practices to survive in challenging environments with 
limited ecological resources. ${ }^{1-3}$ Traditionally, diabetes mellitus (DM) has been uncommon among highlanders ${ }^{45}$ compared with lowlanders. ${ }^{6} 7$ Lifestyle-related diseases, such as DM and hypertension, are rapidly increasing with an increase in longevity and changes in lifestyle worldwide. A remarkable increase in DM has been reported in lowlander and semi-high altitude (around $1300 \mathrm{~m}$ ) migrants who moved from traditional lifestyles to Westernised lifestyles. ${ }^{8-10}$ Prevention of DM has become an urgent issue among lowlanders, especially in developing countries, where the rate of DM prevalence is much faster than in developed countries. $^{11}{ }^{12}$ Older people with a low economic status in rural areas might be vulnerable to impaired glucose tolerance or DM in developed and developing countries. ${ }^{13} 14$ An adverse intrauterine environment is a risk factor of diabetes, ${ }^{15}$ and there is an association between low birth weight and type 2 diabetes. ${ }^{16}$ These phenomena all show adaptation to a low-caloric intake, and the rapid change to a high intake likely increases the risk of diabetes, possibly through a mechanism related to epigenetics. $^{17} 18$

People living at high altitudes not only have the previously mentioned risk factors, but they are also subject to hypoxia in a severe natural environment. ${ }^{19}$ High-altitude dwellers show long-term adaptation to harsh environment-induced hypoxia. Highlanders are biologically adapted to hypoxic environments by various genetic mechanisms, such as an increase in haemoglobin concentrations or increased blood flow without polycythaemia. $^{20} 21$ Andean people have increased haemoglobin levels as a result of hypoxic adaptation, but they suffer from chronic mountain sickness with excessive polycythaemia as a maladaptation to hypoxia more often than Tibetan people do. ${ }^{22}$ Ageing, menopause, respiratory disorders, obesity and hypertension are risk factors of chronic mountain sickness. ${ }^{23-26}$ As a result of rapid lifestyle changes related to urbanisation, highlanders are experiencing an alarming increase in diabetes. ${ }^{27-30}$ Tibetan residents, especially those who are obese, may be more vulnerable to glucose intolerance ${ }^{31}$ compared with Andean people. ${ }^{52}$ Whether high-altitude dwellers are more vulnerable to diabetes as a result of lifestyle changes, compared with lowlanders, is unknown, but people living at high altitudes are known to be vulnerable to hypertension. $43-36$

A population-based study of the effects of high altitude, between 1200 and $3000 \mathrm{~m}$, on the same ethnic group, showed a low prevalence of impaired glucose regulation at high altitudes. ${ }^{37}$ Also, an inverse association has been shown between diabetes and altitudes lower than $3500 \mathrm{~m}$ in lowlanders. ${ }^{38}$ Additionally, lowland patients with diabetes show better glucose intolerance improvement at a mildly high altitude. ${ }^{39}$ However, there are no reports on whether dwelling at altitudes over $3500 \mathrm{~m}$ and hypoxaemia increases the risk of diabetes. We previously reported a strong association between glucose intolerance and polycythaemia in elderly
Tibetan people living in two highland areas. ${ }^{40}$ Because they had adapted to hypoxia by reducing polycythaemia, polycythaemia may be regarded as a sign of maladaptation to hypoxia for Tibetan people.

The aim of this study was to clarify the association of glucose intolerance with hypoxaemia or dwelling at altitudes of $2900-4800 \mathrm{~m}$ in Tibetan highlanders, and to verify the hypothesis that high-altitude dwelling in Tibetan highlanders increases their vulnerability to DM when accelerated by lifestyle change or ageing. This hypothesis is based both on the current accelerated and modernised lifestyle change occurring in middle-aged and elderly highlanders coming from a traditional childhood lifestyle, and on the high prevalence of polycythaemia in elderly Tibetan highlanders in contrast with younger Tibetans.

\section{METHODS}

\section{Study population}

This cross-sectional epidemiological study was carried out from 2008 to 2011. A total of 1258 participants aged 40-87 years (mean age $\pm \mathrm{SD}, 58.0 \pm 11.5$ years) were examined. The study population consisted of consecutive volunteers who attended our medical camps held in three highland communities in China as follows: 86 Tibetan nomads (mean age, 66.7 \pm 5.3 years; male/ female: 40/46) living in a Tibetan nomadic village in Haiyan County (altitude, 3000-3100 m) in 2008; 324 Tibetan urban residents $(59.3 \pm 10.6$ years; $127 / 197)$ in Jiegu Town $(3700 \mathrm{~m})$ in 2009 ; and 41 Tibetan nomads in Ryuho (4200-4400 m) in 2011 in Yushu County, Qinghai (table 1).

Participants in three highland communities in Ladakh, India, were examined as follows: 295 Ladakhi farmers $(57.3 \pm 12.0$ years, $113 / 182)$ in Domkhar village (2900$3800 \mathrm{~m}$ ) in 2009; 308 urban residents (42 Ladakhi/266 Tibetan) (58.1 \pm 12.2 years, $126 / 182)$ in Leh Town $(3300 \mathrm{~m})$ in 2010; and 204 nomads (126 Ladakhi/78 Tibetan) $(54.4 \pm 10.9$ years, $113 / 91)$ in six villages in Changthang (4300-4800 m) in 2011. The participants consisted of people aged 40 years or older, except for 86 participants in Haiyan who were elderly people aged 60 years or older. Announcements for recruitment were carried out by health staff of Qinghai University and health centres in a nomadic village in Haiyan, and in two villages in Ryuho and Jiegu Town. Announcements were also made to people aged 40 years or older by health staff from Ladakh Institute of Prevention, from health centres and from village leaders in the three villages in Domkhar, four villages in Changthang and five colonies of migrants in Leh. We carried out health checks of the volunteer participants in health centres or community halls in rural villages or towns.

Haiyan County (population, 38000 ) contains a Tibetan nomadic village with 465 people aged 60 years or older, ${ }^{41} 42$ who were all invited as volunteer participants for medical check-ups. Eighty-six agreed to take 
Table 1 Characteristics of the field sites in high-altitude regions

\begin{tabular}{lllll}
\hline Rural/urban & Area & Altitude (m above MSL) & $\mathbf{n}$ (male/female) & Livelihood \\
\hline Rural & Domkhar in Ladakh & $2900-3800$ & $295(113 / 182)$ & Farmer \\
& Changthang in Ladakh & $4300-4800$ & $204(113 / 91)$ & Livestock-rearing nomads \\
& Haiyan in Qinghai & $3000-3100$ & $86(40 / 46)$ & Livestock-rearing nomads \\
\multirow{4}{*}{ Urban } & Ryuho in Qinghai & $4200-4400$ & $41(22 / 19)$ & Livestock-rearing nomads \\
& Leh Town in Ladakh & 3300 & $308(126 / 182)$ & Urban lifestyle \\
\hline MSL, mean sea level. & Jiegu Town in Yushu, Qinghai & 3700 & $324(127 / 197)$ & Urban lifestyle \\
\hline
\end{tabular}

part. The study site in Haiyan County was located between an agricultural area inhabited by Han Chinese and a pastoral area inhabited by native Tibetans. ${ }^{43}$

Ryuho consists of six villages with a total population of 8700 , including 1604 residents aged 40 years or older. ${ }^{44}$ People in two representative villages were invited to participate in medical check-ups and 41 Tibetan nomads agreed. Their lifestyle is difficult because of the high altitude and severe cold. They move from one pasture (altitude approximately $4100 \mathrm{~m}$ ) to another (approximately $5000 \mathrm{~m}$ ) and back every 6 months, along with their livestock.

Jiegu Town, with a population of 23000 , is the seat of Yushu County (population, 67 000) in a nomadic area of Qinghai on the Tibetan plateau. With socioeconomic globalisation, this town is a rapidly developing area (population in 1996, 6460). ${ }^{45} 46$ People aged 40 years or older were randomly invited for medical check-ups and 324 of the urban Tibetan residents agreed to participate. These participants had varied occupations, which included being active or retired nomads, farmers or official workers. They were considered to have a lifestyle similar to city dwellers.

Domkhar in Ladakh is a rural village along the Domkhar valley, which consists of the three communities of Dho, Barma and Gongma, at altitudes of 2900, 3400 and $3800 \mathrm{~m}$, respectively, with a total population of 1269 people, including 449 aged 40 years or older. ${ }^{47}$ All were invited for medical check-ups, of whom 295 Ladakhi farmers agreed to volunteer as participants in the survey. The area was not easily accessible and Domkhar has only begun to experience the effects of socioeconomic globalisation in the past few years. Most residents were active farmers with traditional lifestyles, who had experienced changes in their food habits and received access to electricity.

Since the 1970s, the residents of Leh Town have had a history of migration from the Changthang area; they comprise Tibetan as well as Ladakhi nomads. From four representative colonies (population 1435), 637 people aged 40 years or older were invited as volunteer participants for medical check-ups, and 308 of these urban residents (266 Tibetans and 42 Ladakhis) agreed to participate in the survey. They were included in the urban population group because they were considered to have adopted a lifestyle similar to that of city dwellers.
Changthang is the highest plateau (altitude 4300$4800 \mathrm{~m}$ ) among the regions included in this study. From five representative villages (total population 1840), 491 people aged 40 years or older were invited for medical check-ups and 204 nomads (78 Tibetans and 126 Ladakhis) voluntarily agreed to participate. This population is generally made up of nomads who move with their livestock from pasture to pasture every 3 months. Their lifestyle is difficult because of the high altitude and severe cold.

\section{Measurements}

Anthropometric measurements, including weight and height, were obtained using standard techniques. Body mass index (BMI) was calculated as weight $(\mathrm{kg}) /$ height $\left(\mathrm{m}^{2}\right)$. Blood pressure was measured on the arm using an automatic device (HEM 7000; Omron Life Science Co Ltd, Kyoto, Japan) based on the cuff oscillometric principle, and its accuracy has been validated in previous studies. ${ }^{48}$ Oxyhaemoglobin saturation $\left(\mathrm{SpO}_{2}\right)$ was measured by a pulse oximeter (PULSOX-300; Konica Minolta Co Ltd, Tokyo, Japan). Blood pressure and $\mathrm{SpO}_{2}$ were measured twice, in the sitting position, after taking a 5 min rest, at least, and the mean systolic blood pressure (SBP), diastolic blood pressure (DBP) and $\mathrm{SpO}_{2}$ were calculated. Hypertension was defined as SBP $\geq 140 \mathrm{~mm} \mathrm{Hg}$ and/or DBP of $\geq 90 \mathrm{~mm} \mathrm{Hg}$ and/or taking current antihypertensive medicine. ${ }^{49}$

Overnight fasting venous samples were collected in the morning from all participants. Blood glucose was analysed in venous whole blood by a new-generation StatStrip analyser (Nova Biomedical, Boston, Massachusetts, USA), which has been validated as being affected by neither haematocrit ${ }^{50-52}$ nor high altitude. ${ }^{53}$ Additionally, the StatStrip is as accurate for measuring plasma glucose as a standard laboratory analyser is, ${ }^{50-52}$ although previous analysers were influenced by haematocrit ${ }^{50-52}$ and high altitude. ${ }^{54}$ Haemoglobin $(\mathrm{Hb})$ was analysed by the Hemocue haemoglobinometer (Hemocue, Angelholm, Sweden). ${ }^{55} 56$ Samples were analysed at $15-25^{\circ} \mathrm{C}$. Lipids were analysed by either a central laboratory in Qinghai University Hospital, China, or at SRL Inc, India.

Stages of glucose tolerance were classified into either normoglycaemia (NG) or hyperglycaemia (HG) by an oral glucose tolerance test (OGTT) according to WHO 
criteria. The presence of HG consisting of DM and intermediate HG (IHG) was defined as follows: DM was fasting blood glucose (FBG) levels $\geq 7.0 \mathrm{mmol} / \mathrm{L}$ or $2 \mathrm{~h}$ blood glucose levels of $\geq 11.1 \mathrm{mmol} / \mathrm{L}$, and $\mathrm{IHG}$ was fasting glucose levels $\geq 6.1 \mathrm{mmol} / \mathrm{L}$ and $<7.0 \mathrm{mmol} / \mathrm{L}$ or $2 \mathrm{~h}$ glucose levels $\geq 7.8 \mathrm{mmol} / \mathrm{L}$ and $<11.1 \mathrm{mmol} / \mathrm{L}$. Fasting NG and fasting HG were defined using only FBG results. Fasting HG consisted of fasting IHG (FBG levels $\geq 6.1$ and $<7.0 \mathrm{mmol} / \mathrm{L}$ ) and fasting DM (FBG levels $\geq 7.0 \mathrm{mmol} / \mathrm{L}) .^{57}$

Overweight was defined as a BMI of 25 or over. Dyslipidaemia was defined as triglycerides $\geq 150 \mathrm{mg} / \mathrm{dL}$, total cholesterol $\geq 220 \mathrm{mg} / \mathrm{dL}$ and/or high-density lipoprotein (HDL) cholesterol $<40 \mathrm{mg} / \mathrm{dL}$. Hypoxaemia was defined as $\mathrm{SpO}_{2}<89 \mathrm{~mm} \mathrm{Hg}$. Levels of $\mathrm{Hb}$ were classified into four groups: anaemia $(\mathrm{Hb}<13 \mathrm{~g} / \mathrm{dL}$ for males and $<12 \mathrm{~g} / \mathrm{dL}$ for females), normal ( $\mathrm{Hb}<18$ and $\geq 13 \mathrm{~g} / \mathrm{dL}$ for males and $\mathrm{Hb}<16$ and $\geq 12 \mathrm{~g} / \mathrm{dL}$ for females), moderate polycythaemia $(\mathrm{Hb}<21$ and $\geq 18 \mathrm{~g} / \mathrm{dL}$ for males and $\mathrm{Hb}<19$ and $\geq 16 \mathrm{~g} / \mathrm{dL}$ for females) and excessive polycythaemia $(\mathrm{Hb} \geq 21 \mathrm{~g} / \mathrm{dL}$ for males and $\geq 19 \mathrm{~g} / \mathrm{dL}$ for females).

Levels of glycated $\mathrm{Hb}$ (HbA1c) based on the National Glycohemoglobin Standardization Program (NGSP) were analysed by Latex agglutination immunoassay (DCA 2000 HbA1c, Siemens Healthcare Co Ltd, Munich, Germany) in 949 participants in all the field sites except for participants in Haiyan. The frequencies of HbA1c levels $\geq 6.0 \%$ and $\geq 6.5 \%$ were compared among the different classifications of glucose intolerance.

The age of the participants was confirmed with reference to carefully prepared cross-tabulation correlating their date of birth with the animal year, which the rural population always remembered, and with historical sentinel events in the case of elderly participants. The interviewers asked participants whether they currently or previously smoked or currently drank alcohol.

\section{Statistics}

The $\chi^{2}$ test, Student $\mathrm{t}$ test and one-way analysis of variance (ANOVA) were conducted to analyse: the rate of prevalence of glucose intolerance, hypertension, overweight, hypoxaemia, dyslipidaemia, anaemia and polycythaemia; altitude level, dwelling area and livelihood; mean blood glucose, SBP, DBP, BMI, $\mathrm{SpO}_{2}$, lipids and $\mathrm{Hb}$ levels. The associations of glucose intolerance with the confounding factors, including altitude, hypoxaemia, age, sex, overweight, dyslipidaemia and livelihood, were analysed by multiple logistic regression analysis. Analyses were performed using SPSS V.17.0 (SPSS Inc, Chicago, Illinois, USA). A p value $<0.05$ was considered statistically significant.

\section{RESULTS}

The characteristics of all of the studied variables and the differences by sex are shown in table 2. Male participants were older with a lower prevalence of overweight than female participants. They also had a higher prevalence of IHG/fasting IHG, DM/fasting DM, high triglyceride levels, low HDL levels and dyslipidaemia, excessive polycythaemia and a lower prevalence of anaemia than female participants. In addition, male participants were more prevalent at altitudes over $4500 \mathrm{~m}$ and as nomads than female participants, but females were more prevalent as farmers and urban dwellers. The prevalence of current or past smokers was $4.7 \%$ (males $9.4 \%$ and females $1.1 \%$ ). The prevalence of current alcohol drinkers was $25.4 \%$ (males $35.7 \%$ and females $17.6 \%)$.

The characteristics of all the studied variables by difference in age are shown in table 3. Male participants were more prevalent at age 70 years or older. The prevalence of dyslipidaemia and hypertension was higher in older participants. Older people were also more prevalent as urban dwellers, but less prevalent in dwelling over $4500 \mathrm{~m}$. Prevalence of hypoxaemia $\left(\mathrm{SpO}_{2}<89 \%\right)$ was higher in older participants, but not for anaemia and excessive polycythaemia.

Table 4 shows the association of glucose intolerance (fasting IHG/fasting DM or IHG/DM), using the criteria of FBG and OGTT, with all of the studied variables. Glucose intolerance increased with age. Glucose intolerance was also associated with male sex, overweight, dyslipidaemia, hypertension, hypoxaemia, high $\mathrm{Hb}$ levels, high HbAlc levels, high altitude and urban dwellers/farmers (vs nomads). Neither smoking nor drinking alcohol was associated with glucose intolerance.

The prevalence of glucose intolerance, overweight, dyslipidaemia, hypertension, hypoxaemia and polycythaemia are shown at different altitude areas in farmers, nomads and urban dwellers (table 5). In farmers, the prevalence of fasting HG using the FBG criterion was significantly increased with elevation of altitude $(2900,3400$ and $3800 \mathrm{~m})$ in the three communities of Dho, Barma and Gongma ( $\mathrm{n}=106(16.0 \%), 74$ $(20.3 \%), \quad 115$ (34.8\%), respectively, $\mathrm{p}=0.0033)$ in Domkhar, Ladakh. The prevalence of HG, using the OGTT criterion in the three communities, was also increased $(30.2 \%, 36.5 \%, 43.5 \%$, respectively), but not significantly. In comparison, between the two altitude levels of $<3500 \mathrm{~m}$ (Dho and Barma) and $\geq 3500 \mathrm{~m}$ (Gongma), the prevalence of glucose intolerance using the FBG criterion was significantly increased with elevation of altitude (fasting HG: $17.8 \%$ vs $34.8 \%$, fasting DM: $3.3 \%$ vs $10.4 \%$, HbA1c >6.0\%: $15.5 \%$ vs $29.9 \%$ ) in spite of the low prevalence of overweight people dwelling at a higher altitude compared with those at a lower altitude (table 5).

A comparison of nomad participants was conducted between Haiyan and Ryuho in Qinghai, and the prevalence of fasting HG using the FBG criterion was found to increase, but not significantly $(8.1 \%$ vs $12.2 \%)$ with elevation of altitude (3000-3100 vs $4200-4400 \mathrm{~m})$. In Changthang-1 and Changthang-2 in Ladakh, the 


\begin{tabular}{|c|c|c|c|c|}
\hline & All & Male & Female & p Value \\
\hline$N$ & 1258 & 541 & 717 & \\
\hline (\%) & & 43.0 (40.3 to 45.7$)$ & 57.0 (54.3 to 59.7$)$ & \\
\hline Age (years) & $58.0 \pm 11.5$ & $58.9 \pm 11.8$ & $57.3 \pm 11.2$ & 0.0120 \\
\hline Height (cm) & $157.4 \pm 9.4$ & $163.9 \pm 8.1$ & $152.4 \pm 7.0$ & $<0.0001$ \\
\hline Weight (kg) & $60.8 \pm 13.9$ & $64.8 \pm 13.1$ & $57.8 \pm 13.7$ & $<0.0001$ \\
\hline BMI & $24.4 \pm 4.5$ & $24.0 \pm 4.1$ & $24.7 \pm 4.9$ & 0.0064 \\
\hline Overweight (BMI>25) (\%) & 40.1 (37.4 to 42.8$)$ & 36.6 (32.5 to 40.7 ) & 42.8 (39.2 to 46.4$)$ & 0.0259 \\
\hline \multicolumn{5}{|l|}{ Blood glucose } \\
\hline FBG (mg/dL) & $101.3 \pm 24.5$ & $104.7 \pm 29.6$ & $98.7 \pm 19.5$ & $<0.0001$ \\
\hline $2 \mathrm{~h}-\mathrm{BG}(\mathrm{mg} / \mathrm{dL})$ & $124.9 \pm 50.1$ & $129.3 \pm 58.6$ & $121.6 \pm 42.3$ & 0.0068 \\
\hline Fasting IHG/Fasting DM (\%) & $12.7(10.9$ to 14.5$) / 6.5$ (5.1 to 7.9$)$ & $15.3(12.3$ to 18.3$) / 9.6$ (7.1 to 12.1$)$ & $10.7(8.4$ to 13.0$) / 4.2(2.7$ to 5.7$)$ & $<0.0001$ \\
\hline IHG/DM (\%) & 25.1 (22.7 to 27.5$) / 8.9$ (7.3 to 10.5$)$ & $27.5(23.7$ to 31.3$) / 12.0(9.3$ to 14.7$)$ & $23.3(20.2$ to 26.4$) / 6.6$ (4.8 to 8.4$)$ & 0.0002 \\
\hline Dyslipidaemia & 34.8 (32.2 to 37.4$)$ & 38.3 (34.2 to 42.4$)$ & $32.2(28.3$ to 36.1$)$ & 0.0259 \\
\hline Triglycerides & $98.5 \pm 58.3$ & $104.8 \pm 56.5$ & $93.7 \pm 59.3$ & 0.0012 \\
\hline Triglycerides $\geq 150$ mg/dL (\%) & $12.3(10.5$ to 14.1$)$ & $16.0(12.9$ to 19.1$)$ & $9.6(7.1$ to 12.1$)$ & 0.0011 \\
\hline Total cholesterol & $187.3 \pm 46.2$ & $185.5 \pm 45.2$ & $188.4 \pm 47.4$ & NS \\
\hline Total cholesterol $\geq 220$ mg/dL (\%) & 21.9 (19.6 to 24.2$)$ & 20.1 (16.7 to 23.5$)$ & $23.3(20.2$ to 26.4$)$ & NS \\
\hline HDL cholesterol & $52.6 \pm 16.2$ & $50.7 \pm 20.2$ & $54.1 \pm 12.0$ & 0.0003 \\
\hline HDL cholesterol<40 mg/dL (\%) & $13.8(11.9$ to 15.7$)$ & $19.3(16.0$ to 22.6$)$ & $9.6(7.4$ to 11.8$)$ & $<0.0001$ \\
\hline $\mathrm{SBP}(\mathrm{mm} \mathrm{HG})$ & $134.0 \pm 25.1$ & $135.6 \pm 23.4$ & $132.8 \pm 26.3$ & 0.0507 \\
\hline DBP (mm HG) & $85.6 \pm 14.4$ & $86.0 \pm 14.2$ & $85.2 \pm 14.5$ & NS \\
\hline Hypertension (\%) & 40.4 (37.7 to 43.1$)$ & 42.7 (38.5 to 46.9 ) & 38.7 (35.1 to 42.3$)$ & NS \\
\hline \multicolumn{5}{|l|}{ Livelihood } \\
\hline Farmer (\%) & 23.5 (21.2 to 25.8$)$ & 20.9 (17.5 to 24.3$)$ & 25.4 (22.2 to 28.6$)$ & 0.0001 \\
\hline Nomad (\%) & 26.3 (23.9 to 28.7$)$ & 32.3 (28.4 to 36.2$)$ & 21.8 (18.8 to 24.8$)$ & \\
\hline Urban dweller (\%) & $50.2(47.4$ to 53.0$)$ & 46.8 (42.6 to 51.0$)$ & $52.9(49.2$ to 56.6$)$ & \\
\hline Altitude (m) & $3641.7 \pm 523.3$ & $3691.7 \pm 562.3$ & $3603.9 \pm 488.9$ & 0.0032 \\
\hline \multicolumn{5}{|l|}{ Altitude level (\%) } \\
\hline $2500-3499 \mathrm{~m}$ & 45.6 (42.8 to 48.4$)$ & 44.4 (40.2 to 48.6$)$ & 46.6 (42.9 to 50.3 & 0.0002 \\
\hline $3500-4499 m$ & 41.9 (39.2 to 44.6$)$ & 38.8 (34.7 to 42.9$)$ & $44.2(40.6$ to 47.8$)$ & \\
\hline $4500+m$ & 12.5 (10.7 to 14.3$)$ & 16.8 (13.6 to 20.0$)$ & $9.2(7.1$ to 11.3$)$ & \\
\hline $\mathrm{SpO}_{2}(\%)$ & $90.6 \pm 4.3$ & $90.8 \pm 4.1$ & $90.5 \pm 4.4$ & NS \\
\hline Hypoxaemia $\left(\mathrm{SpO}_{2}<89 \%\right)(\%)$ & 25.2 (22.8 to 27.6$)$ & 25.0 (21.4 to 28.6$)$ & 25.4 (22.2 to 28.6$)$ & NS \\
\hline $\mathrm{Hb}(\mathrm{g} / \mathrm{dL})$ & $15.6 \pm 2.7$ & $17.1 \pm 2.3$ & $14.5 \pm 2.4$ & $<0.0001$ \\
\hline \multicolumn{5}{|l|}{ Group according to $\mathrm{Hb}(\%)$} \\
\hline Anaemia & $7.5(6.0$ to 9.0$)$ & $2.0(0.8$ to 3.2$)$ & $11.6(9.3$ to 13.9$)$ & $<0.0001$ \\
\hline Normal & $56.4(53.7$ to 59.1$)$ & $59.3(55.2$ to 63.4$)$ & $54.3(50.7$ to 57.9$)$ & \\
\hline Moderate polycythaemia & 27.7 (25.2 to 30.2$)$ & $24.8(21.2$ to 28.4$)$ & $29.8(26.5$ to 33.1$)$ & \\
\hline Excessive polycythaemia & $8.4(6.9$ to 9.9$)$ & $13.9(11.0$ to 16.8$)$ & $4.3(2.8$ to 5.8$)$ & \\
\hline $\begin{array}{l}\text { Values are mean } \pm \mathrm{SD} \text {, or } \%(95 \% \mathrm{Cl}) . \\
\text { Data were analysed using } \chi^{2} \text { test for compe } \\
2 \mathrm{~h}-\mathrm{BG}, 2 \mathrm{~h} \text { blood glucose following } 75 \mathrm{~g} \text { O } \\
\text { IHG, fasting intermediate hyperglycaemia }\end{array}$ & $\begin{array}{l}\text { of the rates of variables, and by the St } \\
\text { MI, body mass index; DBP, diastolic b } \\
\text {; FBG, fasting blood glucose; Hb, hae }\end{array}$ & $\begin{array}{l}\text { t test for comparison of variables betwee } \\
\text { ressure; DM, diabetes mellitus by OGTT } \\
\text { bin; HDL, high-density lipoprotein; NS, na }\end{array}$ & $\begin{array}{l}\text { les and females. } \\
\text { ting DM, fasting diabetes mellitus by FBC } \\
\text { nnificant; OGTT, oral glucose tolerance te }\end{array}$ & $\begin{array}{l}\text { sting } \\
\text { SBP, }\end{array}$ \\
\hline
\end{tabular}


Table 3 Characteristics of the studied variables by age

\begin{tabular}{|c|c|c|c|c|c|}
\hline & \multicolumn{4}{|l|}{ Age (years) } & \multirow[t]{2}{*}{ p Value } \\
\hline & $40-49$ & 50-59 & $60-69$ & $70+$ & \\
\hline $\mathrm{N}$ & 354 & 287 & 384 & 233 & \\
\hline Male (vs female) (\%) & 42.1 (37.0 to 47.2$)$ & 38.3 (32.7 to 43.9$)$ & 41.9 (37.0 to 46.8$)$ & 51.9 (45.5 to 58.3$)$ & 0.0152 \\
\hline Overweight (BMI $\geq 25)(\%)$ & 39.8 (34.7 to 44.9$)$ & 38.0 (32.4 to 43.6$)$ & 42.7 (37.8 to 47.6$)$ & 39.1 (32.8 to 45.4$)$ & NS \\
\hline Dyslipidaemia (\%) & 29.1 (24.4 to 33.8$)$ & 30.7 (25.4 to 36.0$)$ & 42.7 (37.0 to 48.4$)$ & $35.6(30.1$ to 41.1$)$ & 0.0005 \\
\hline Triglycerides $\geq 150 \mathrm{mg} / \mathrm{dL}$ & 10.7 (7.5 to 13.9$)$ & 13.3 (9.4 to 17.2$)$ & $14.2(10.7$ to 17.7$)$ & $10.8(6.8$ to 14.8$)$ & NS \\
\hline Total cholesterol $\geq 220 \mathrm{mg} / \mathrm{dL}$ & 12.4 (9.0 to 15.8$)$ & 16.1 (11.8 to 20.4$)$ & 34.6 (29.8 to 39.4$)$ & 24.1 (18.6 to 29.6$)$ & $<0.0001$ \\
\hline HDL cholesterol $<40 \mathrm{mg} / \mathrm{dL}$ & 17.9 (13.9 to 21.9$)$ & 10.7 (7.1 to 14.3$)$ & $11.3(8.1$ to 14.5$)$ & $15.1(10.5$ to 19.7$)$ & 0.0259 \\
\hline Hypertension (\%) & 23.4 (19.0 to 27.8$)$ & 39.0 (33.4 to 44.6$)$ & 44.8 (39.8 to 49.8$)$ & 61.0 (54.7 to 67.3$)$ & $<0.0001$ \\
\hline \multicolumn{6}{|c|}{ - } \\
\hline Farmer & 25.1 (20.6 to 29.6$)$ & 28.6 (23.4 to 33.8$)$ & 18.8 (14.9 to 22.7$)$ & $22.3(17.0$ to 7.6$)$ & 0.0125 \\
\hline Nomad & $29.4(24.7$ to 34.1$)$ & 23.7 (18.8 to 28.6$)$ & 28.4 (23.9 to 32.9$)$ & 21.5 (16.2 to 26.8$)$ & \\
\hline Urban dweller & 45.5 (40.3 to 50.7$)$ & 47.7 (41.9 to 53.5$)$ & 52.9 (47.9 to 57.9$)$ & 56.2 (49.8 to 62.6$)$ & \\
\hline \multicolumn{6}{|l|}{ Altitude level (\%) } \\
\hline $2500-3499 \mathrm{~m}$ & 41.5 (36.4 to 46.6$)$ & 46.3 (40.5 to 52.1$)$ & 43.5 (38.5 to 48.5$)$ & 54.5 (48.1 to 60.9$)$ & $<0.0001$ \\
\hline $3500-4499 \mathrm{~m}$ & 42.1 (37.0 to 47.2$)$ & 36.9 (31.3 to 42.5$)$ & 47.1 (42.1 to 52.1$)$ & 39.1 (32.8 to 45.4$)$ & \\
\hline $4500+m$ & 16.4 (12.5 to 20.3$)$ & 16.7 (12.4 to 21.0$)$ & 9.4 (6.5 to 12.3$)$ & 6.4 (3.3 to 9.5$)$ & \\
\hline \multicolumn{6}{|l|}{ Hypoxaemia } \\
\hline $\mathrm{SpO}_{2}<89 \%(\%)$ & 20.1 (15.9 to 24.3 ) & 23.7 (18.8 to 28.6$)$ & 26.3 (21.9 to 30.7 ) & 33.0 (27.0 to 39.0$)$ & 0.0043 \\
\hline \multicolumn{6}{|l|}{ Group according to $\mathrm{Hb}(\%)$} \\
\hline Anaemia & 13.3 (9.8 to 16.8$)$ & 5.2 (2.6 to 7.8$)$ & 4.7 (2.6 to 6.8$)$ & 6.0 (3.0 to 9.0$)$ & $<0.0001$ \\
\hline Normal & 49.4 (44.2 to 54.6$)$ & 54.4 (48.6 to 60.2$)$ & 59.9 (55.0 to 64.8$)$ & 63.9 (57.7 to 70.1$)$ & \\
\hline Polycythae & 24.9 (20.4 to 29.4$)$ & 31.0 (25.6 to 36.4$)$ & 29.9 (25.3 to 34.5$)$ & 24.0 (18.5 to 29.5$)$ & \\
\hline Excessive polycythaemia & $12.4(9.0$ to 15.8$)$ & 9.4 (6.0 to 12.8$)$ & 5.5 (3.2 to 7.8$)$ & 6.0 (3.0 to 9.0$)$ & \\
\hline
\end{tabular}

Values are $\%(95 \% \mathrm{Cl})$.

$\mathrm{BMI}$, body mass index; $\mathrm{Hb}$, haemoglobin; $\mathrm{HDL}$, high-density lipoprotein; $\mathrm{SpO}_{2}$, oxyhaemoglobin saturation measured by pulse oximeter.

prevalence of fasting HG using FBG criterion increased $(12.8 \%$ vs $21.0 \%)$ with elevation of altitude (4300-4400 vs $4500-4800 \mathrm{~m}$ ), but not significantly, while the prevalence of fasting DM significantly increased $(0.0 \%$ vs $8.9 \%, \mathrm{p}=0.0339)$. Comparing the three altitude levels, $<3500$ (Haiyan), 3500-4499 (Ryuho and Changthang-1) and $\geq 4500 \mathrm{~m}$ (Changthang-2), the prevalence of glucose intolerance with the FBG criterion was significantly increased with elevation of altitude (fasting HG: $8.1 \%$ (Haiyan) vs $12.5 \%$ (Ryuho and Changthang-1) vs $21.0 \%$ (Changthan-2), fasting DM: $3.5 \%$ vs $2.3 \%$ vs $8.9 \%$ ) despite the low prevalence of overweight and dyslipidaemia in people dwelling at a higher altitude than at a lower altitude (table 5).

In urban dwellers, using both criteria to measure fasting $\mathrm{HG}$, fasting $\mathrm{DM}, \mathrm{HG}, \mathrm{DM}$ and $\mathrm{HbAlc}$, showed that the prevalence of glucose intolerance increased significantly with elevation of altitude (table 5). The results also indicated a greater prevalence of overweight and hyperlipidaemia in people dwelling at a higher altitude than in those at a lower altitude. Prevalence of hypertension was not associated with altitude levels in farmers, nomads and urban dwellers.

Prevalence of hypoxaemia and polycythaemia was significantly increased with elevation of altitude in all the groups of farmers, nomads and urban dwellers.

The association of the variables $\mathrm{Hb}$, overweight and glucose intolerance, with hypoxaemia $\left(\mathrm{SpO}_{2}<89 \%\right)$ as the dependent variable, was separately analysed after adjustment for age, sex and altitude levels, using multiple logistic regression (models 1-3). Polycythaemia (model 1), overweight (models 2 and 3), fasting HG (model 2$)$, fasting DM (OR=1.70, CI 1.02 to 2.85 , vs no fasting DM, $\mathrm{p}=0.0413$ ), HG (model 3) and DM $(\mathrm{OR}=1.90$, CI 1.21 to 2.96 , vs no $\mathrm{DM}, \mathrm{P}=0.0049)$ were associated with hypoxaemia independent of altitude levels (see online supplementary table S1).

The variables that were associated with glucose intolerance and adjusted for age and sex in the four models (for dependent variables of fasting HG, fasting DM, HG and $\mathrm{DM}$ ) by multiple logistic regression analysis are shown in table 6. Overweight (all models), hypoxaemia (all models), dyslipidaemia (all models), polycythaemia (all models), farmers (models for fasting HG and for HG, vs nomads) and urban dwellers (models for HG vs nomads) were associated with glucose intolerance after adjustment for age and sex. Altitude level of 3500$4499 \mathrm{~m}$ was closely associated with all models, while the highest level of $\geq 4500 \mathrm{~m}$ was associated with fasting HG and fasting DM, but not with HG or DM. By classifying the altitude level into two groups of 2500-3499 and $\geq 3500 \mathrm{~m}$ and analysing by multiple logistic regression, the altitude level of $\geq 3500 \mathrm{~m}$ was closely associated with glucose intolerance in all the models compared with 2500-3499 $\mathrm{m}$ altitude.

The associations of high altitude, hypoxaemia and polycythaemia with glucose intolerance and adjusted for related variables in the four models were analysed by 
Table 4 Variables associated with glucose intolerance

\begin{tabular}{|c|c|c|c|c|c|c|c|c|c|}
\hline & All & Fasting NG & $\begin{array}{l}\text { By FBG } \\
\text { Fasting IHG }\end{array}$ & Fasting DM & $p$ Value & NG & $\begin{array}{l}\text { By OGTT } \\
\text { IHG }\end{array}$ & DM & $p$ Value \\
\hline $\mathrm{N}$ & 1258 & 1016 & 160 & 82 & & 830 & 316 & 112 & \\
\hline$\%$ & & 80.8 (78.6 to 83.0 ) & 12.7 (10.9 to 14.5$)$ & 6.5 (5.1 to 7.9$)$ & & 66.3 (63.7 to 68.9 ) & 24.9 (22.5 to 27.3 ) & 8.8 (7.2 to 10.4$)$ & \\
\hline Sex & $\mathrm{n}$ & $(\%)$ & $(\%)$ & $(\%)$ & & $(\%)$ & & $(\%)$ & \\
\hline Male & 541 & 75.0 (71.4 to 78.6$)$ & 15.3 (12.3 to 18.3 ) & $9.6(7.1$ to 12.1$)$ & $<0.0001$ & 60.4 (56.3 to 64.5$)$ & 27.5 (23.7 to 31.1$)$ & $12.0(9.3$ to 14.7$)$ & 0.0002 \\
\hline Female & 717 & 85.1 (82.5 to 87.7 ) & $10.7(8.4$ to 13.0$)$ & $4.2(2.7$ to 5.7$)$ & $<0.0001$ & $70.2(66.9$ to 73.5$)$ & 23.3 (20.2 to 26.4$)$ & 6.6 (4.8 to 8.4$)$ & \\
\hline Age (years) & $\mathrm{n}$ & $(\%)$ & $(\%)$ & $(\%)$ & 0.1012 & $(\%)$ & (\%) & $(\%)$ & 0.0005 \\
\hline $40-49$ & 354 & 84.7 (80.9 to 88.5 ) & 10.5 (7.3 to 13.7$)$ & 4.8 (2.6 to 7.0$)$ & & 72.6 (68.0 to 77.2 ) & 21.8 (17.5 to 26.1$)$ & 5.7 (3.3 to 8.1$)$ & \\
\hline $50-59$ & 287 & 82.2 (77.8 to 86.6$)$ & $11.2(7.6$ to 14.8$)$ & 6.6 (3.7 to 9.5 ) & & 70.7 (65.4 to 76.0$)$ & 20.2 (15.6 to 24.8 ) & 9.1 (5.8 to 12.4$)$ & \\
\hline $60-69$ & 384 & 75.8 (71.5 to 80.1$)$ & 15.9 (12.2 to 19.6$)$ & $8.3(5.5$ to 11.1$)$ & & 60.9 (56.0 to 65.8$)$ & 27.6 (23.1 to 32.1$)$ & 11.5 (8.3 to 14.7$)$ & \\
\hline $70+$ & 233 & 81.1 (76.1 to 86.1 ) & 12.9 (8.6 to 17.2$)$ & $6.0(3.0$ to 9.0$)$ & & 58.4 (52.1 to 64.7$)$ & 32.2 (26.2 to 38.2 ) & $9.4(5.7$ to 13.1$)$ & \\
\hline BMI & $\mathrm{n}$ & (\%) & $(\%)$ & $(\%)$ & & $(\%)$ & (\%) & $(\%)$ & \\
\hline Normal & 753 & 84.1 (81.5 to 86.7 ) & 11.0 (8.8 to 13.2$)$ & $4.9(3.4$ to 6.4$)$ & 0.0008 & 72.0 (68.8 to 75.2$)$ & 21.4 (18.5 to 24.3 ) & 6.6 (4.8 to 8.4$)$ & $<0.0001$ \\
\hline $\begin{array}{l}\text { Overweight (BMI } \\
\geq 25 \% \text { ) }\end{array}$ & 505 & 75.8 (72.1 to 79.5 ) & 15.2 (12.1 to 18.3$)$ & $8.9(6.4$ to 11.4$)$ & & 57.0 (52.7 to 61.3$)$ & 30.7 (26.7 to 34.7$)$ & 12.3 (9.4 to 15.2$)$ & \\
\hline Dyslipidaemia & $\mathrm{n}$ & $(\%)$ & $(\%)$ & $(\%)$ & & $(\%)$ & $(\%)$ & $(\%)$ & \\
\hline Normal & 820 & 84.1 (81.6 to 86.6$)$ & 11.5 (9.3 to 13.7$)$ & 4.4 (3.0 to 5.8$)$ & $<0.0001$ & 70.0 (66.9 to 73.1$)$ & 24.3 (21.4 to 27.2 ) & $5.7(4.1$ to 7.3$)$ & $<0.0001$ \\
\hline Dyslipidaemia & 438 & 74.4 (70.3 to 78.5$)$ & 15.1 (11.7 to 18.5$)$ & 10.5 (7.6 to 13.4$)$ & & 58.4 (53.8 to 63.0$)$ & 26.7 (22.6 to 30.8 ) & 14.8 (11.5 to 18.1$)$ & \\
\hline Blood pressure & $\mathrm{n}$ & (\%) & $(\%)$ & $(\%)$ & & (\%) & (\%) & (\%) & \\
\hline Normal & 749 & 83.3 (80.6 to 86.0 ) & 11.5 (9.2 to 13.8$)$ & 5.2 (3.6 to 6.8$)$ & 0.0220 & 70.9 (67.6 to 74.2$)$ & 22.3 (19.3 to 25.3 ) & 6.8 (5.0 to 8.6 ) & $<0.0001$ \\
\hline Hypertension & 509 & 77.4 (73.8 to 81.0$)$ & 14.3 (11.3 to 17.3$)$ & 8.3 (5.9 to 10.7$)$ & & 59.1 (54.8 to 63.4$)$ & 29.3 (25.3 to 33.3 ) & 11.6 (8.8 to 14.4$)$ & \\
\hline Livelihood & $\mathrm{n}$ & $(\%)$ & $(\%)$ & $(\%)$ & & $(\%)$ & $(\%)$ & $(\%)$ & \\
\hline Farmer & 295 & 75.6 (70.7 to 80.5 ) & 18.3 (13.9 to 22.7 ) & 6.1 (3.4 to 8.8 ) & 0.0140 & 63.1 (57.6 to 68.6 ) & 28.5 (23.3 to 33.7$)$ & 8.5 (5.3 to 11.7$)$ & 0.0001 \\
\hline Nomad & 331 & 84.6 (80.7 to 88.5 ) & 9.7 (6.5 to 12.9$)$ & 5.7 (3.2 to 8.2$)$ & & 76.1 (71.5 to 80.7 ) & 15.7 (11.8 to 19.6$)$ & $8.2(5.2$ to 11.2$)$ & \\
\hline Urban dweller & 632 & 81.2 (78.2 to 84.2$)$ & 11.7 (9.2 to 14.2$)$ & 7.1 (5.1 to 9.1 ) & & 62.0 (58.2 to 65.8$)$ & 28.5 (25.0 to 32.0$)$ & 9.5 (7.2 to 11.8$)$ & \\
\hline Altitude level (m) & $\mathrm{n}$ & $(\%)$ & $(\%)$ & $(\%)$ & & $(\%)$ & $(\%)$ & $(\%)$ & \\
\hline $2500-3499$ & 574 & 88.3 (85.7 to 90.9 ) & $8.5(6.2$ to 10.8$)$ & 3.1 (1.7 to 4.5$)$ & $<0.0001$ & 70.7 (67.0 to 74.4$)$ & 23.2 (19.7 to 26.7 ) & 6.1 (4.1 to 8.1$)$ & $<0.0001$ \\
\hline 3500-4499 & 527 & 73.1 (69.5 to 76.7 ) & 17.5 (14.4 to 20.6$)$ & 9.5 (7.1 to 11.9$)$ & & 58.1 (54.1 to 62.1 ) & 30.2 (26.4 to 34.0$)$ & $11.8(9.2$ to 14.4$)$ & \\
\hline $4500+$ & 157 & 79.0 (72.6 to 85.4$)$ & 12.1 (7.0 to 17.2$)$ & $8.9(4.4$ to 13.4$)$ & & 75.2 (68.4 to 82.0$)$ & $15.3(9.7$ to 20.9$)$ & 9.6 (5.0 to 14.2$)$ & \\
\hline $\mathrm{SpO}_{2}$ & $\mathrm{n}$ & $(\%)$ & $(\%)$ & $(\%)$ & & $(\%)$ & $(\%)$ & $(\%)$ & \\
\hline Normal & 941 & 83.2 (80.8 to 85.6 ) & 11.5 (9.5 to 13.5 ) & 5.3 (3.9 to 6.7$)$ & 0.0004 & $68.2(65.2$ to 71.2$)$ & 24.4 (21.7 to 27.1$)$ & $7.3(5.6$ to 9.0$)$ & 0.0010 \\
\hline $\begin{array}{l}\text { Hypoxaemia } \\
\left(\mathrm{SpO}_{2}<89 \%\right)\end{array}$ & 317 & 73.5 (68.6 to 78.4 ) & 16.4 (12.3 to 20.5$)$ & $10.1(6.8$ to 13.4$)$ & & 59.3 (53.9 to 64.7 ) & 27.1 (22.2 to 32.0 ) & 13.6 (9.8 to 17.4$)$ & \\
\hline $\begin{array}{l}\text { Group according } \\
\text { to } \mathrm{Hb}\end{array}$ & $\mathrm{n}$ & $(\%)$ & $(\%)$ & $(\%)$ & & (\%) & (\%) & $(\%)$ & \\
\hline Anaemia & 94 & 86.2 (79.2 to 93.2$)$ & 11.7 (5.2 to 18.2$)$ & 2.1 (0 to 5.0 ) & $<0.0001$ & 73.4 (64.5 to 82.3 ) & 23.4 (14.8 to 32.0$)$ & 3.2 (0 to 6.8 ) & $<0.0001$ \\
\hline Normal & 710 & 86.3 (83.8 to 88.8 ) & 10.1 (7.9 to 12.3$)$ & 3.5 (2.1 to 4.9$)$ & & $71.3(68.0$ to 74.6$)$ & 23.2 (20.1 to 26.3 ) & 5.5 (3.8 to 7.2 ) & \\
\hline Polycythaemia & 348 & 73.3 (68.7 to 77.9$)$ & 16.4 (12.5 to 20.3 ) & $10.3(7.1$ to 13.5$)$ & & 57.5 (52.3 to 62.7$)$ & 29.0 (24.2 to 33.8 ) & $13.5(9.9$ to 17.1$)$ & \\
\hline \multirow[t]{2}{*}{$\begin{array}{l}\text { Excessive } \\
\text { polycythaemia }\end{array}$} & 106 & 63.2 (54.0 to 72.4 ) & 18.9 (11.4 to 26.4 ) & 17.9 (10.6 to 25.2$)$ & & 51.9 (42.4 to 61.4$)$ & 26.4 (18.0 to 34.8$)$ & 21.7 (13.9 to 29.5$)$ & \\
\hline & & & & & & & & & Continu \\
\hline
\end{tabular}




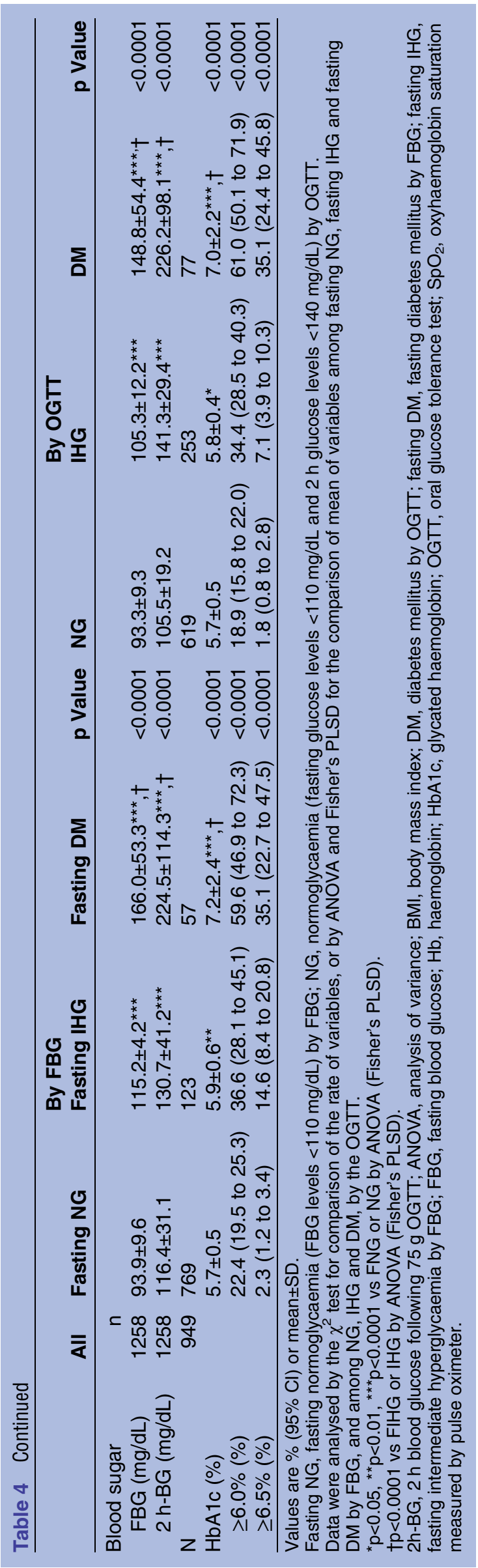

multiple logistic regression (table 7). For the dependent variables of glucose intolerance (fasting $\mathrm{HG} /$ fasting DM) as measured using the FBG criterion, the results showed that dwelling at high altitudes was a closely associated factor (ORs of fasting HG/fasting DM for $>4500$ and $3500-3999 \mathrm{~m}$ were $3.59 / 4.36$ and $2.07 / 1.76$ vs $<3500 \mathrm{~m}$ ) independent of hypoxaemia and the lifestyle-related factors of overweight and livelihood. Classifying the altitude levels into two groups, 2500-3499 and $\geq 3500 \mathrm{~m}$, and using multiple logistic regression analysis, the $\geq 3500 \mathrm{~m}$ altitude level was also closely associated with fasting $\mathrm{HG}(\mathrm{OR}=2.19$, CI 1.53 to 3.12, $\mathrm{p}<0.0001)$ and fasting $\mathrm{DM}(\mathrm{OR}=1.94$, CI 1.06 to 3.55 , $\mathrm{p}=0.0305$ ), but not with HG and not with DM. For the dependent variables of glucose intolerance (HG and DM), using the OGTT criterion, there was no association with dwelling at a high altitude, but hypoxaemia was a closely associated factor. Polycythaemia, overweight, dyslipidaemia, farmers and urban dwellers were also closely associated with glucose intolerance according to both criteria. Hypertension was not associated with glucose intolerance by multivariate analysis.

The effect of livelihood or ethnicity on the association between altitudes and fasting HG was analysed and is shown in online supplementary table S2. In models 1-3, multivariate analyses were carried out separately in each livelihood of farmer, nomad and urban dweller. In farmers and nomads, higher altitude had significantly higher OR for fasting HG compared with lower altitude, but not in urban dwellers after adjustment with other confounding factors. In models 4 and 5, multivariate analysis was carried out separately in each ethnic group, Tibetan and Ladakhi. Higher altitude had significantly greater OR compared with lower altitude in both groups. The OR was higher in the Ladakhi (2.53 vs 1.69) than in the Tibetan group. In models 6 and 7 , multivariate analysis was carried out in all participants, and higher altitude had significantly greater OR compared with lower altitude independently of livelihood and ethnicity (see online supplementary table S2).

\section{DISCUSSION}

Association of hypoxaemia with glucose intolerance

The association of glucose intolerance with lifestyle-related health factors and hypoxaemia was studied in 1258 residents dwelling at a wide range of altitudes from 2900 to $4800 \mathrm{~m}$ in the Tibetan highland Previous studies have reported a negative association between glucose intolerance and altitudes below $3500 \mathrm{~m}$ in Tibetans ${ }^{37}$ and lowlanders. ${ }^{38}$ To the best of our knowledge, we showed, for the first time, epidemiological evidence of a positive association between the prevalence of fasting glucose intolerance at high altitudes over $3500 \mathrm{~m}$ and independently of hypoxaemia. These positive effects of dwelling at high altitudes were more distinct when glucose intolerance was defined by FBG. The association of high altitude $\geq 3500 \mathrm{~m}$ with fasting $\mathrm{HG}$ was 
Table 5 Prevalence of glucose intolerance and other variables at different altitudes, in farmers, nomads and urban dwellers

\begin{tabular}{|c|c|c|c|c|}
\hline \multirow[b]{3}{*}{ Farmer } & \multicolumn{4}{|c|}{ Altitude (m above MSL) } \\
\hline & \multirow{2}{*}{$2500-3499 \mathrm{~m}$} & \multirow[t]{2}{*}{ 3500-4499 m } & \multirow[t]{2}{*}{$4500+m$} & \multirow[t]{2}{*}{ p Value } \\
\hline & & & & \\
\hline & $\begin{array}{l}\text { Dho and Barma } \\
(2900-3400 \mathrm{~m})\end{array}$ & $\begin{array}{l}\text { Gongma } \\
(3800 \mathrm{~m})\end{array}$ & & \\
\hline & $n=180$ & $n=115$ & & \\
\hline Age & $56.7 \pm 12.7$ & $58.0 \pm 11.5$ & & NS \\
\hline Male (\%) & 41.3 (34.1 to 48.5$)$ & 33.9 (25.2 to 42.6$)$ & & NS \\
\hline Fasting hyperglycaemia (\%) & 17.8 (12.2 to 23.4$)$ & 34.8 (26.1 to 43.5$)$ & & 0.0009 \\
\hline Fasting DM (\%) & $3.3(0.7$ to 5.9$)$ & 10.4 (4.8 to 16.0$)$ & & 0.0129 \\
\hline Hyperglycaemia (\%) & 32.8 (25.9 to 39.7$)$ & 43.5 (34.4 to 52.6$)$ & & 0.0633 \\
\hline $\mathrm{DM}(\%)$ & $7.2(3.4$ to 11.0$)$ & 10.4 (4.8 to 16.0$)$ & & NS \\
\hline Overweight (\%) & 21.7 (15.7 to 27.7$)$ & $11.3(5.5$ to 17.1$)$ & & 0.0227 \\
\hline Dyslipidaemia (\%) & 16.7 (11.3 to 22.1$)$ & 17.4 (10.5 to 24.3$)$ & & NS \\
\hline Hypertension (\%) & 34.4 (27.5 to 41.3$)$ & 41.7 (32.7 to 50.7$)$ & & NS \\
\hline Hypoxaemia (\%) & $13.3(8.3$ to 18.3$)$ & 30.4 (22.0 to 38.8$)$ & & 0.0004 \\
\hline \multirow[t]{2}{*}{ Polycythaemia (moderate and excessive) (\%) } & $18.4(12.7$ to 24.1$)$ & 35.6 (26.8 to 44.4$)$ & & 0.0014 \\
\hline & $\mathrm{n}=161$ & $\mathrm{n}=107$ & & \\
\hline $\mathrm{HbA1c} \geq 6.0 \%(\%)$ & 15.5 (9.9 to 21.1$)$ & 29.9 (21.2 to 38.6$)$ & & 0.0048 \\
\hline \multicolumn{5}{|l|}{ Nomad } \\
\hline & & $\begin{array}{l}\text { Ryuho and } \\
\text { Chnqthanq-1 }\end{array}$ & & \\
\hline & $(3000-3100 \mathrm{~m})$ & $(4100-4400 \mathrm{~m})$ & $(4500-4800 \mathrm{~m})$ & \\
\hline & $\mathrm{n}=86$ & $\mathrm{n}=88$ & $n=157$ & \\
\hline Age & $66.7 \pm 5.3$ & $52.6 \pm 10.8$ & $54.5 \pm 10.5$ & $<0.0001$ \\
\hline Male (\%) & 46.5 (36.0 to 57.0$)$ & 50.0 (39.6 to 60.4$)$ & $58.0(50.3$ to 65.7$)$ & NS \\
\hline Fasting hyperglycaemia (\%) & $8.1(2.3$ to 13.8$)$ & $12.5(5.6$ to 19.4$)$ & 21.0 (14.6 to 27.4$)$ & 0.0197 \\
\hline Fasting DM (\%) & $3.5(0$ to 7.4$)$ & $2.3(0$ to 5.4$)$ & $8.9(4.4$ to 13.4$)$ & 0.0581 \\
\hline Hyperglycaemia (\%) & $20.9(12.3$ to 29.5$)$ & $25.0(16.0$ to 34.0$)$ & 24.8 (18.0 to 31.6$)$ & NS \\
\hline $\mathrm{DM}(\%)$ & 8.1 (2.3 to 13.9$)$ & $5.7(0.9$ to 10.5$)$ & $9.6(5.0$ to 14.2$)$ & NS \\
\hline Overweight (\%) & 40.7 (30.3 to 51.1$)$ & 40.9 (30.6 to 51.2$)$ & 19.7 (13.5 to 25.9$)$ & 0.0002 \\
\hline Dyslipidaemia (\%) & 59.3 (48.9 to 69.7$)$ & 45.5 (35.1 to 55.9$)$ & 26.1 (19.2 to 33.0$)$ & $<0.0001$ \\
\hline Hypertension (\%) & 34.9 (24.8 to 45.0$)$ & $23.9(15.0$ to 32.8$)$ & 24.8 (18.0 to 31.6$)$ & NS \\
\hline Hypoxaemia (\%) & 25.6 (16.4 to 34.8$)$ & 36.2 (26.2 to 46.2$)$ & 63.7 (56.2 to 71.2$)$ & $<0.0001$ \\
\hline Polycythaemia (moderate and excessive) (\%) & 36.1 (25.9 to 46.3 ) & $\begin{array}{l}64.7(54.7 \text { to } 74.7) \\
n=73\end{array}$ & $\begin{array}{l}64.3 \text { (56.8 to } 71.8) \\
n=118\end{array}$ & 0.0016 \\
\hline $\mathrm{HbA} 1 \mathrm{c} \geq 6.0 \%(\%)$ & - & 24.7 (14.8 to 34.6$)$ & 26.3 (18.4 to 34.2 ) & NS \\
\hline \multicolumn{5}{|l|}{ Urban dweller } \\
\hline & $\begin{array}{l}\text { Leh Town, Ladakh } \\
(3300 \mathrm{~m})\end{array}$ & $\begin{array}{l}\text { Yushu, Qinghai } \\
\text { (3700 m) }\end{array}$ & & \\
\hline & $\mathrm{n}=308$ & $\mathrm{n}=324$ & & \\
\hline Age & $58.1 \pm 12.2$ & $59.3 \pm 10.6$ & & NS \\
\hline Male (\%) & 40.9 & 39.2 & & NS \\
\hline Fasting hyperglycaemia (\%) & 9.1 (5.9 to 12.3$)$ & 28.1 (23.2 to 33.0$)$ & & $<0.0001$ \\
\hline Fasting DM (\%) & $2.9(1.0$ to 4.8$)$ & $11.1(7.7$ to 14.5$)$ & & $<0.0001$ \\
\hline Hyperglycaemia (\%) & 29.5 (24.4 to 34.6$)$ & 46.0 (40.6 to 51.4$)$ & & $<0.0001$ \\
\hline $\mathrm{DM}(\%)$ & 4.9 (2.5 to 7.3$)$ & $13.9(10.1$ to 17.7$)$ & & 0.0001 \\
\hline Overweight (\%) & $42.9(37.4$ to 48.4$)$ & $67.6(62.5$ to 72.7$)$ & & $<0.0001$ \\
\hline Dyslipidaemia (\%) & 24.0 (19.2 to 28.8$)$ & 56.2 (50.8 to 61.6$)$ & & $<0.0001$ \\
\hline Hypertension (\%) & 48.1 (42.5 to 53.7$)$ & 49.4 (44.0 to 54.8$)$ & & NS \\
\hline Hypoxaemia (\%) & $8.4(5.3$ to 11.5$)$ & 27.8 (22.9 to 32.7$)$ & & $<0.0001$ \\
\hline Polycythaemia (moderate and excessive) (\%) & $10.1(6.7$ to 13.5$)$ & 49.4 (44.0 to 54.8$)$ & & $<0.0001$ \\
\hline & $\mathrm{n}=305$ & $\mathrm{n}=185$ & & \\
\hline $\mathrm{HbA1c} \geq 6.0 \%(\%)$ & 22.3 (17.6 to 27.0$)$ & 41.6 (34.5 to 48.7$)$ & & $<0.0001$ \\
\hline
\end{tabular}

Values are mean $\pm \mathrm{SD}, \mathrm{n}$, or $\%(95 \% \mathrm{Cl})$.

Data were analysed by the $\chi^{2}$ test for comparison of the rate of variables, or by the ANOVA for age among the different altitude groups.

ANOVA, analysis of variance; DM, diabetes mellitus; HbA1c, glycated haemoglobin; MSL, mean sea level; NS, not significant. 
Table 6 Variables associated with glucose intolerance adjusted for age and sex by multiple logistic regression analysis

\begin{tabular}{|c|c|c|c|c|c|c|c|c|c|c|c|c|}
\hline & \multicolumn{3}{|c|}{ Fasting hyperglycaemia } & \multicolumn{3}{|l|}{ Fasting DM } & \multicolumn{3}{|c|}{ Hyperglycaemia (OGTT) } & \multicolumn{3}{|c|}{ DM (OGTT) } \\
\hline & OR & $\mathrm{Cl}$ & p Value & $\overline{\text { OR }}$ & $\mathrm{Cl}$ & p Value & $\overline{\text { OR }}$ & $\mathrm{Cl}$ & p Value & $\overline{\text { OR }}$ & $\mathrm{Cl}$ & p Value \\
\hline \multicolumn{13}{|l|}{ Age (years) } \\
\hline $40-49$ & Reference & & & Reference & & & Reference & & & Reference & & \\
\hline $50-59$ & 1.20 & (0.79 to 1.83$)$ & NS & 1.41 & (0.72 to 2.76$)$ & NS & 1.10 & $(0.78$ to 1.55$)$ & NS & 1.66 & (0.91 to 3.05$)$ & 0.0992 \\
\hline $60-69$ & 1.78 & (1.22 to 2.58$)$ & 0.0025 & 1.80 & (0.98 to 3.31$)$ & 0.0572 & 1.70 & (1.25 to 2.32$)$ & 0.0008 & 2.16 & (1.25 to 3.75$)$ & 0.006 \\
\hline $70+$ & 1.29 & (0.84 to 2.00$)$ & NS & 1.27 & (0.61 to 2.62$)$ & NS & 1.89 & (1.33 to 2.68$)$ & 0.0004 & 1.74 & (0.93 to 3.27$)$ & 0.0843 \\
\hline Male (vs female) & 1.90 & (1.43 to 2.52$)$ & $<0.0001$ & 2.44 & (1.54 to 3.89$)$ & 0.0002 & 1.54 & (1.22 to 1.95$)$ & 0.0003 & 1.95 & (1.31 to 2.89 ) & 0.0009 \\
\hline $\begin{array}{l}\text { Overweight (BMI } \\
\geq 25 \text { ) }\end{array}$ & 1.77 & (1.33 to 2.36$)$ & $<0.0001$ & 2.05 & (1.30 to 3.23$)$ & 0.0022 & 2.02 & (1.58 to 2.57 ) & $<0.0001$ & 2.10 & (1.41 to 3.12 ) & 0.0003 \\
\hline Dyslipidaemia & 1.70 & (1.27 to 2.27 ) & 0.0003 & 2.38 & (1.50 to 3.76$)$ & 0.0002 & 1.56 & (1.22 to 1.99$)$ & 0.0004 & 2.69 & (1.80 to 4.01$)$ & $<0.0001$ \\
\hline $\begin{array}{l}\text { Triglycerides } \\
\geq 150\end{array}$ & 3.28 & (2.26 to 4.77 ) & $<0.0001$ & 3.25 & (1.93 to 5.48$)$ & $<0.0001$ & 2.79 & (1.95 to 3.99$)$ & $<0.0001$ & 3.7 & (2.33 to 5.89 ) & $<0.0001$ \\
\hline $\begin{array}{l}\text { Total } \\
\text { cholesterol } \\
\geq 220\end{array}$ & 1.71 & (1.22 to 2.38 ) & 0.0018 & 2.49 & (1.52 to 4.08 ) & 0.0003 & 1.6 & (1.19 to 2.14 ) & 0.0017 & 2.88 & (1.88 to 4.43 ) & $<0.0001$ \\
\hline $\begin{array}{l}\mathrm{HDL} \\
\text { cholesterol }<40\end{array}$ & 1.50 & (1.01 to 2.23 ) & 0.0441 & 1.70 & (0.95 to 3.03 ) & 0.0736 & 1.4 & (0.99 to 1.98$)$ & 0.0579 & 1.39 & (0.81 to 2.39 ) & NS \\
\hline $\begin{array}{l}\text { Hypertension } \\
\text { Livelihood }\end{array}$ & 1.40 & (1.04 to 1.87 ) & 0.0272 & 1.58 & (0.99 to 2.52 ) & 0.0544 & 1.53 & (1.20 to 1.96$)$ & 0.0007 & 1.68 & (1.12 to 2.52 ) & 0.0128 \\
\hline Farmer & 2.06 & (1.37 to 3.11 ) & 0.0005 & 1.24 & (0.63 to 2.43 ) & NS & 2.10 & (1.47 to 2.99 ) & $<0.0001$ & 1.17 & (0.66 to 2.07 ) & NS \\
\hline Nomad & Reference & & & Reference & & & Reference & & & Reference & & \\
\hline Urban dweller & 1.38 & (0.96 to 2.00 ) & 0.0817 & 1.40 & (0.80 to 2.45 ) & NS & 2.06 & (1.52 to 2.80$)$ & $<0.0001$ & 1.26 & (0.78 to 2.03 ) & NS \\
\hline \multicolumn{13}{|c|}{ Altitude level $(n=1275)$} \\
\hline 2500-3499 m & Reference & & & Reference & & & Reference & & & Reference & & \\
\hline $3500-4499 m$ & 2.87 & (2.07 to 3.97$)$ & $<0.0001$ & 3.31 & (1.90 to 5.79$)$ & $<0.0001$ & 1.80 & (1.40 to 2.33$)$ & $<0.0001$ & 2.10 & (1.36 to 3.26$)$ & 0.0009 \\
\hline $4500+m$ & 1.95 & (1.22 to 3.13$)$ & 0.0055 & 2.81 & (1.35 to 5.88$)$ & 0.006 & 0.82 & (0.54 to 1.24$)$ & NS & 1.60 & (0.84 to 3.05$)$ & NS \\
\hline Hypoxaemia & & & & & & & & & & & & \\
\hline $\mathrm{SpO}_{2}<89 \%$ & 1.81 & (1.33 to 2.46$)$ & 0.0002 & 2.06 & (1.29 to 3.29$)$ & 0.0027 & 1.42 & (1.09 to 1.86$)$ & 0.0098 & 1.99 & (1.32 to 2.99$)$ & 0.0010 \\
\hline \multicolumn{13}{|c|}{ Group according to $\mathrm{Hb}$} \\
\hline Anaemia & 1.44 & (0.76 to 2.75$)$ & NS & 0.92 & (0.21 to 4.01$)$ & NS & 1.17 & (0.70 to 1.93$)$ & NS & 0.83 & (0.25 to 2.78$)$ & NS \\
\hline Normal & Reference & & & Reference & & & Reference & & & Reference & & \\
\hline $\begin{array}{l}\text { Moderate } \\
\text { polycythaemia }\end{array}$ & 2.50 & (1.80 to 3.46$)$ & $<0.0001$ & 3.48 & (2.03 to 5.95 ) & $<0.0001$ & 1.98 & (1.50 to 2.60 ) & $<0.0001$ & 2.92 & (1.86 to 4.60$)$ & $<0.0001$ \\
\hline $\begin{array}{l}\text { Excessive } \\
\text { polycythaemia }\end{array}$ & 3.67 & (2.30 to 5.86 ) & $<0.0001$ & 5.75 & (2.97 to 11.14 ) & $<0.0001$ & 2.44 & (1.59 to 3.74 ) & $<0.0001$ & 4.97 & (2.77 to 8.94 ) & $<0.0001$ \\
\hline
\end{tabular}


Table 7 Associations of high-altitude, hypoxaemia and polycythaemia with glucose intolerance adjusted for all other confounders by multiple logistic regression analysis

\begin{tabular}{|c|c|c|c|c|c|c|c|c|c|c|c|c|}
\hline & \multicolumn{2}{|c|}{ Fasting hyperglycaemia } & \multirow[b]{2}{*}{ p Value } & \multicolumn{2}{|c|}{ Fasting DM } & \multirow[b]{2}{*}{ p Value } & \multicolumn{2}{|c|}{$\begin{array}{l}\text { Hyperglycaemia } \\
\text { (OGTT) }\end{array}$} & \multirow[b]{2}{*}{ p Value } & \multicolumn{2}{|l|}{ DM (OGTT) } & \multirow[b]{2}{*}{ p Value } \\
\hline & OR & $\mathrm{Cl}$ & & $\overline{\text { OR }}$ & $\mathrm{Cl}$ & & $\overline{\text { OR }}$ & $\mathrm{Cl}$ & & OR & $\mathbf{C I}$ & \\
\hline \multicolumn{13}{|l|}{ Age (years) } \\
\hline $40-49$ & Reference & & & Reference & & & Reference & & & Reference & & \\
\hline $50-59$ & 1.21 & $(0.77$ to 1.91$)$ & NS & 1.49 & (0.73 to 3.06$)$ & NS & 1.05 & (0.73 to 1.52$)$ & NS & 1.73 & (0.91 to 3.30$)$ & 0.0951 \\
\hline $60-69$ & 2.03 & (1.34 to 3.07 ) & 0.0008 & 2.06 & (1.06 to 4.02 ) & 0.0336 & 1.73 & (1.23 to 2.43$)$ & 0.0016 & 2.34 & (1.28 to 4.27$)$ & 0.0057 \\
\hline $70+$ & 1.36 & (0.83 to 2.22$)$ & NS & 1.38 & (0.62 to 3.06$)$ & NS & 1.79 & (1.21 to 2.65$)$ & 0.0035 & 1.77 & (0.89 to 3.54$)$ & NS \\
\hline Male (vs female) & 2.17 & (1.57 to 2.99$)$ & $<0.0001$ & 2.5 & (1.50 to 4.18$)$ & 0.0004 & 1.68 & (1.29 to 2.18$)$ & 0.0001 & 1.95 & (1.26 to 3.01 ) & 0.0026 \\
\hline Overweight & 1.68 & (1.18 to 2.40$)$ & 0.0041 & 1.43 & (0.82 to 2.52 ) & NS & 1.66 & (1.25 to 2.21 ) & 0.0004 & 1.46 & (0.91 to 2.35 ) & NS \\
\hline Dyslipidaemia & 1.59 & (1.14 to 2.22$)$ & 0.0058 & 2.11 & (1.26 to 3.54$)$ & 0.0048 & 1.38 & (1.05 to 1.81$)$ & 0.023 & 2.51 & (1.60 to 3.92$)$ & $<0.0001$ \\
\hline Hypertension & 1.09 & (0.78 to 1.50$)$ & NS & 1.18 & (0.71 to 1.96$)$ & NS & 1.16 & (0.88 to 1.51$)$ & NS & 1.26 & (0.82 to 1.95$)$ & NS \\
\hline \multicolumn{13}{|l|}{ Livelihood } \\
\hline Farmer & 6.62 & (3.56 to 12.32) & $<0.0001$ & 5.61 & (1.90 to 16.55$)$ & 0.0018 & 3.83 & (2.38 to 6.15$)$ & $<0.0001$ & 3.10 & (1.40 to 6.86$)$ & 0.0051 \\
\hline Nomad & Reference & & & Reference & & & Reference & & & Reference & & \\
\hline Urban dweller & 2.53 & (1.42 to 4.49$)$ & 0.0015 & 3.47 & (1.28 to 9.42 ) & 0.0145 & 2.66 & (1.74 to 4.07 ) & $<0.0001$ & 1.96 & (0.96 to 3.99 ) & 0.0641 \\
\hline \multicolumn{13}{|l|}{ Altitude level } \\
\hline 2500-3499 m & Reference & & & Reference & & & Reference & & & Reference & 1 & \\
\hline 3500-4499 m & 2.07 & (1.44 to 2.98$)$ & $<0.0001$ & 1.76 & (0.94 to 3.28 ) & 0.0767 & 1.23 & (0.92 to 1.64$)$ & NS & 1.08 & (0.65 to 1.78 ) & NS \\
\hline $4500+m$ & 3.59 & (1.75 to 7.37 ) & 0.0005 & 4.36 & (1.33 to 14.31$)$ & 0.0150 & 1.25 & (0.70 to 2.23$)$ & NS & 1.46 & (0.59 to 3.65$)$ & NS \\
\hline \multicolumn{13}{|l|}{ Hypoxaemia } \\
\hline $\mathrm{SpO}_{2}<89 \%$ & 1.48 & (1.04 to 2.10$)$ & 0.0305 & 1.56 & (0.92 to 2.65$)$ & 0.099 & 1.45 & (1.07 to 1.97$)$ & 0.0183 & 1.72 & (1.09 to 2.73 ) & 0.0202 \\
\hline \multicolumn{13}{|c|}{ Group according to $\mathrm{Hb}$} \\
\hline Anaemia & 1.47 & (0.75 to 2.89$)$ & NS & 0.95 & $(0.21$ to 4.24$)$ & NS & 1.24 & (0.74 to 2.08$)$ & NS & 0.84 & (0.25 to 2.89$)$ & NS \\
\hline Normal & Reference & & & Reference & & & Reference & & & Reference & & \\
\hline $\begin{array}{c}\text { Moderate } \\
\text { polycythaemia }\end{array}$ & 2.00 & (1.39 to 2.87 ) & 0.0002 & 2.57 & (1.44 to 4.60$)$ & 0.0014 & 1.90 & (1.40 to 2.58$)$ & $<0.0001$ & 2.34 & (1.42 to 3.84$)$ & 0.0008 \\
\hline $\begin{array}{c}\text { Excessive } \\
\text { polycythaemia }\end{array}$ & 3.58 & (2.11 to 6.06$)$ & $<0.0001$ & 5.46 & (2.62 to 11.38 ) & $<0.0001$ & 3.16 & (1.94 to 5.15$)$ & $<0.0001$ & 5.35 & (2.76 to 10.34$)$ & $<0.0001$ \\
\hline
\end{tabular}




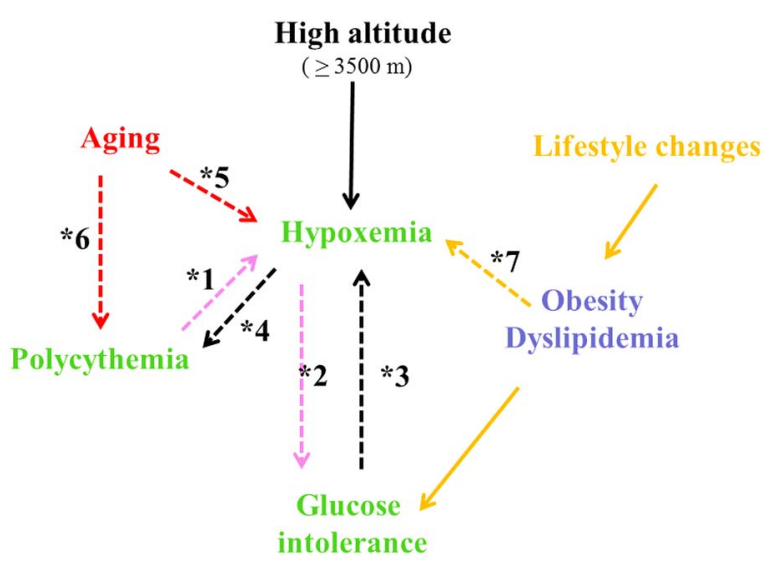

Figure 1 Hypothesised associations of hypoxaemia, polycythaemia and glucose intolerance with the influence of ageing and lifestyle change. Hypothesis $1\left({ }^{*} 1\right.$ and *2) and hypothesis 2 ( ${ }^{*} 3$ and $\left.{ }^{*} 4\right)$ in the association of hypoxia, polycythaemia and glucose intolerance. Ageing and lifestyle change accelerate the association, 'Diabetes acceleration hypothesis'. *1 or 4: Proposed according to online supplementary table S1 and table 5. *2 or 3: Proposed according to data in tables 6 and 7 , online supplementary table S1, and previous studies. ${ }^{58-64 *} 1$ and *2: Proposed according to a previous study. ${ }^{6}{ }^{*} 3$ and * 4 : Proposed according to previous studies. ${ }^{76} 77{ }^{\star} 5$ : Proposed according to table 3. *6: Proposed according to our data compared with a previous study. ${ }^{74}{ }^{*} 7$ : Proposed according to online supplementary table $\mathrm{S} 1$.

shown even after adjustment of the effects of both lifestyle and ethnicity in all participants, and also in a separate analysis of farmers and nomads, but not in urban dwellers. Analysis of hypoxaemia, using $\mathrm{SpO}_{2}$, was closely associated with a high prevalence of glucose intolerance as measured by FBG and OGTT after adjustment for both dwelling at high altitude and all lifestyle-related health factors (figure 1).

\section{Comparison with other studies on the association between hypoxaemia and glucose intolerance}

No previous reports have shown an association between hypoxia and glucose intolerance in high-altitude dwellers. However, there are some reports on the association of hypoxaemia with glucose intolerance in lowlanders $^{58-63}$ and in animals. ${ }^{64}$ People with respiratory diseases, ${ }^{58}$ sleep apnoea syndrome ${ }^{6061}$ and insomnia, ${ }^{62} 63$ have a high prevalence of glucose intolerance. An isolated high fasting glucose pattern in a glucose tolerance test was dominant and insulin resistance increased in these people. ${ }^{60-63}$ High-altitude dwellers have more severe hypoxaemia during sleep than during waking hours, and the prevalence of insomnia was higher in people dwelling at higher altitudes. Aggravation of insulin resistance in an acute hypoxic environment has also been reported to be caused not only by an increase in stress hormones, including epinephrine and corticosteroid, but also by the direct effect of hypoxia. ${ }^{59}$ Although there are no reports on humans showing vulnerability to glucose intolerance in newborns from mothers who have hypoxaemia, this has been reported in calves (figure 1). ${ }^{64}$

In our previous study on lowlanders aged 40 years or older in Tosa, Japan, the prevalence of HG (fasting HG) and DM (fasting DM) was $46.2 \%(22.7 \%$ ) and $16.7 \%$ $(6.8 \%)$, respectively. ${ }^{65}$ In that study, the percentages of 'fasting $\mathrm{HG}$ in $\mathrm{HG}$ ' ('fasting $\mathrm{DM}$ in DM') were $49.1 \%$ $(40.7 \%)$. Those percentages were calculated using the same data as in table 5 and they increased parallel with altitude (2500-3499 vs 3500-4499 vs $4500 \mathrm{~m})$. In farmers, the percentages of 'fasting HG in HG' ('fasting $\mathrm{DM}$ in DM') increased with elevation of altitude from $54.3 \%(45.8 \%)$ to $80.0 \%(100 \%)$, in nomads these percentages also increased from $38.8 \%(43.2 \%)$ to $50.0 \%$ $(40.4 \%)$ to $84.7 \%(92.7 \%)$, and in urban dwellers, these percentages increased from $30.8 \%(59.2 \%)$ to $61.1 \%$ $(79.9 \%)$. The percentage of 'fasting $\mathrm{HG}$ in $\mathrm{HG}$ ' in farmers and urban dwellers exceeded 60-80\% above $3500 \mathrm{~m}$, and in nomads, exceeded $80 \%$ above $4500 \mathrm{~m}$. The $2 \mathrm{~h}-\mathrm{BG}$ levels in our result in fasting $\mathrm{IHG} /$ fasting DM were much lower $(130.7 / 224.5 \mathrm{mg} / \mathrm{dL})$ compared with those in Tosa Town (172.4/ $262.6 \mathrm{mg} / \mathrm{dL})$, though FBG levels in our study of fasting IHG/fasting DM $(115.2 / 166.0 \mathrm{mg} / \mathrm{dL})$ were not lower compared with those in Tosa Town $(115.8 / 146.2 \mathrm{mg} / \mathrm{dL})$. These results are compatible with the isolated high fasting glucose pattern and increased insulin resistance in people who have hypoxaemia and stress while sleeping. ${ }^{60-63}$

Our results and previous reports suggest that mild hypoxia and a higher metabolic rate in participants living at an altitude lower than $3500 \mathrm{~m}$ may be preventive for glucose intolerance. However, moderate hypoxia and dwelling at higher altitudes over $3500 \mathrm{~m}$ may increase the risk of fasting glucose intolerance (figure 1).

Hypothesis of associations of polycythaemia, hypoxaemia and glucose intolerance in high-altitude dwellers

An association between polycythaemia and glucose intolerance in a small sample population has been previously reported. ${ }^{40}$ In our study of a large high-altitude population, using multivariate analysis, after adjustment for lifestyle-related factors and hypoxaemia, this association was strong. As a result, we propose the following two hypotheses to explain the mechanism of the strong associations among polycythaemia, hypoxaemia and glucose intolerance. The first hypothesis is that polycythaemia aggravates hypoxaemia and leads to glucose intolerance (*1 and *2 in figure 1 ). This hypothesis was based on the association of polycythaemia with hypoxaemia (table 5 and online supplementary table S1) and the association of hypoxaemia with glucose intolerance (tables 6 and 7).

The cross-sectional design of our study is a limitation to the causal relation. Additionally, there are no longitudinal studies on highlanders. However, a previous longitudinal report on lowlanders in a large 9-year follow-up study supports our hypothesis in which the highest haematocrit group $(>44.3 \%)$ has a higher risk $(\mathrm{OR}=1.6)$ 
of diabetes onset compared with the lowest group $(<39.0 \%) .{ }^{66}$ The mechanism of this association is speculated as follows: lower blood circulation caused by the high viscosity of polycythaemia is considered to disrupt the transport of insulin, glucose and oxygen to tissue cells, resulting in low cellular intake of glucose and lower activity of respiration, which requires oxygen and glucose in cells. ${ }^{66}$ Our study showed an association of anaemia with HG. ${ }^{67}$ This supports our first hypothesis because anaemia results in low activity of $\mathrm{O}_{2}$ transport and subsequent hypoxaemia in tissue, which is aggravated at high altitude. Almost all study participants with anaemia had iron deficiency. ${ }^{67}$ Also, Ladakhi farmers eat less meat than Tibetan nomads do, ${ }^{33} 68$ and are vulnerable to suffering from iron deficiency anaemia.

Polycythaemia may be a sign of maladaptation to hypoxia, which leads to glucose intolerance, because Tibetan people have acquired a hypoxic adaptation by preventing polycythaemia through a genetic response to hypoxia. $^{20} 2169-73$ Tibetans (mean age $34-35$ years, BMI 18.4-18.5) compared with Andean highlanders (mean age 37-38 years, BMI 22.3-23.4) living at similar altitudes $(4000 \mathrm{~m})$ have lower $\mathrm{Hb}$ levels (male/female: 15.6/14.2 vs 19.1/17.8 g/dL, respectively), though participants with anaemia were excluded from this study. ${ }^{74}$ The genes responsible for lower $\mathrm{Hb}$ are PPARA, EGLN1 and EPAS1, and the mean $\mathrm{Hb}$ of both sexes is decreased by these advantageous haplotypes. ${ }^{70}$ The frequency of the adaptive haplotype of EPAS1 is reported to be $87 \%$ in Tibetans and $9 \%$ in Han Chinese. ${ }^{71}$ The sex-adjusted $\mathrm{Hb}$ level is $0.8 \mathrm{~g} / \mathrm{dL}$ lower in homozygotes compared with heterozygotes of EPAS1. ${ }^{69}$

Mean $\mathrm{Hb}$ in our older participants (mean 58.3 years, BMI 24.0-25.1, altitude 2900-4800 m, anaemia was excluded) was $16.1 \mathrm{~g} / \mathrm{dL}$ (male/female: 17.2/15.1), which was $1.6 / 0.9 \mathrm{~g} / \mathrm{dL}$ higher compared with the younger Tibetans (34-35 years) ${ }^{74}$ Excluding overweight participants from the older group, the mean $\mathrm{Hb}$ of these older participants was $1.4 / 0.6 \mathrm{~g} / \mathrm{dL}$ (male/ female) higher compared with that of the younger participants. ${ }^{74}$ Another report showed the associations between age, polycythaemia and the genes that have adapted to hypoxia. Older Tibetan chronic mountain sickness patients (mean age 54 years, $\mathrm{n}=45$ ) have as much as $96 \%$ of the adaptive haplotype EPAS1 compared with $72 \%$ in younger people without polycythaemia (mean age: 30 years, $n=34$ ) ${ }^{75}$ Ageing may aggravate not only hypoxaemia (table 3) but also polycythaemia in Tibetan people $(* 5$ and $* 6$ in figure 1 ), even in those with adaptive haplotypes. ${ }^{75}$

\section{Hypothesis of associations of glucose intolerance,} hypoxaemia and polycythaemia in high-altitude dwellers

Our second hypothesis is that glucose intolerance leads to microvascular complications and aggravation of tissue hypoxaemia. Polycythaemia is enhanced with compensation for this hypoxaemia (*3 and *4 in figure 1 ). The basis of our results for this hypothesis is the same as in the first hypothesis because it was a cross-sectional study without causal relation. However, there are observational studies in lowlanders supporting this hypothesis. ${ }^{76} 77$ Infants have complications of polycythaemia from mothers with diabetes. Chronic intrauterine hypoxaemia intermediates this association. ${ }^{76} 77$

The advantageous homozygotes of the genes that are involved in adaptation to hypoxia (EGLN1 and PPARA) have stronger metabolic effects to facilitate anaerobic glycolysis and regression of lipid catabolism, resulting in higher serum concentrations of lipids by adaptation to hypoxia. 707879 This effect may prevent the development of diabetes in younger people with a traditional lifestyle. However, sedentary workers and elderly people with advantageous genetic adaptations to hypoxia may be vulnerable to obesity, hyperlipidaemia and increased insulin resistance by lifestyle changes compared with people without these advantageous genes. Obesity and dyslipidaemia lead not only to increased insulin resistance (tables 6 and 7), but also to hypoxaemia (see online supplementary table $\mathrm{S} 1$ and $* 7$ in figure 1 ).

Higher $\mathrm{Hb}$ was found in participants in Jiegu Town who were overweight compared with those not overweight. This difference in $\mathrm{Hb}$ (male/female $1.3 / 0.9 \mathrm{~g} / \mathrm{dL}$ ) was higher than the difference of the sexadjusted $\mathrm{Hb}(0.8 \mathrm{~g} / \mathrm{dL})$ in homozygotes compared with heterozygotes of EPAS1. ${ }^{69}$ The effect of lifestyle changes on polycythaemia in our study overcame the acquired hypoxic adaptation for prevention of polycythaemia. People in Jiegu Town $(3700 \mathrm{~m})$ with a high prevalence of overweight also had the highest prevalence of HG and fasting HG. Those parameters were accelerated both by lifestyle changes and by hypoxaemia, with an extremely high frequency of polycythaemia. While people in the higher altitude community of Domkhar $(3800 \mathrm{~m})$ had a low prevalence of overweight, they had a high prevalence of HG with an especially high fasting HG and polycythaemia, which may be accelerated mainly by hypoxia.

Our first hypothesis mainly explains our result of the association of dwelling at high altitude or hypoxaemia with an increase in glucose intolerance as seen in Domkhar. The second hypothesis is mainly associated with our result of lifestyle-related factors leading to an increase in glucose intolerance. According to our results and previous reports, these two hypotheses may be acting simultaneously with each other, considering the close associations among hypoxaemia, polycythaemia and glucose intolerance as seen in Jiegu Town. The association of glucose intolerance with polycythaemia and hypoxaemia is accelerated by ageing and lifestyle changes, and there may be the vulnerability of the hypoxia adaptive genes for glucose intolerance as the background, called the 'Diabetes acceleration hypothesis' (figure 1).

\section{Conclusions, unanswered questions and policy implications}

Socioeconomic factors and hypoxia-the effect of altitudes over $3500 \mathrm{~m}$-play major roles in the prevalence 
of glucose intolerance in highlanders. Hypoxaemia and polycythaemia were closely associated with glucose intolerance after adjustment for the effects of lifestyle changes in our study. Tibetan people may be vulnerable to glucose intolerance, with polycythaemia as a sign of poor hypoxic adaptation. However, the mechanism of the onset of glucose intolerance by hypoxaemia in highaltitude dwellers is unknown. A previous report showed higher oxidative stress in Tibetan people compared with in Han people, and higher oxidative stress was associated with glucose intolerance and arteriosclerosis. ${ }^{80} \quad 81$ Further examination of the metabolic mechanism and oxidative stress in association with the effects of genes involved in hypoxia adaptation in high-altitude dwellers is needed. Because the matter of whether the WHO criteria of glucose intolerance can be applicable in highaltitude people has not been established, the prognosis of fasting $\mathrm{HG}$ and $\mathrm{HG}$ associated with high-altitude should be examined longitudinally. Prevention of lifestyle-related diseases and health education should be advocated, especially in high altitude dwellers, with rapidly prevailing socioeconomic globalisation.

\section{Author affiliations}

${ }^{1}$ Research Department, Research Institute for Humanity and Nature, Kyoto, Japan

${ }^{2}$ Center for Southeast Asian Studies, Kyoto University, Kyoto, Japan

${ }^{3}$ Hakubi Center for Advanced Research, Kyoto University, Kyoto, Japan

${ }^{4}$ Faculty of Medicine, Public Health Nursing, School of Nursing, Mie

University, Tsu, Mie, Japan

${ }^{5}$ Department of Medicine, Tokyo Women's Medical University, Medical Center East, Tokyo, Japan

${ }^{6}$ Health Promotion and Human Behavior, Kyoto University Graduate School of Medicine, Kyoto, Japan

${ }^{7}$ Sakakibara Hakuho Hospital, Tsu, Mie, Japan

${ }^{8}$ College of Nursing, Kanto Gakuin University, Yokohama, Japan

${ }^{9}$ Affiliated Hospital of Qinghai University, Xining, Qinghai, China

${ }^{10}$ Qinghai Academy of Animal and Veterinary Sciences, Xining, Qinghai, China

${ }^{11}$ Research Center for High Altitude Medicine, Qinghai University, Xining, Qinghai, China

${ }^{12}$ Ladakh Institute of Prevention, Ladakh, India

${ }^{13}$ Graduate School of Asian and African Area Studies, Kyoto University, Kyoto, Japan

${ }^{14}$ National Institute for Agro-Environmental Sciences, Ibaragi, Japan

${ }^{15}$ Faculty of Education and Regional Studies, University of Fukui, Fukui, Japan

${ }^{16}$ The Open University of Japan, Chiba, Japan

${ }^{17}$ Yasugi Clinic, Shimane, Japan

${ }^{18}$ Chronomics \& Gerontology, Tokyo Women's Medical University, Tokyo, Japan

Acknowledgements The authors thank the participants and staff of Qinghai University Affiliated Hospital, the People's Hospital of Haiyan and Yushu County, Qinghai, China, Ladakh Institute of Prevention and Health centres in Domkhar and Changthang, and the High-altitude project of Research Institute for Humanity and Nature, Kyoto, Japan. They thank Airong Yang, Zhanquan Li and Haiying Tong (Qinghai University Affiliated Hospital) and also thank Tsering Motup, Rigzin Dolma, Ishey Lhamo, Sherab Dolma, Rinchen Dolma and Kunznag Dolma (Ladakh Institute of Prevention). The authors thank Naomune Yamamoto (Aino Hospital, Osaka, Japan), Shun Nakajima and Reiko Hozo (Tokyo Women's Medical University, Medical Center East, Tokyo, Japan). They acknowledge Yukiko Kita and Chizu Wada for their assistance.

Contributors KO, RS, R-LG, TN, TT, KA, TI, ST, MI, KO and KM were involved in the study conception and design. KO obtained funding. KO, RS, YI, YK, EF, MI, KS, HI, WC, EK, MN, YK, HW, QD, HX, HQ, TN, NT, YK, NM, TY, TT, KA,
TI, ST, MI, KO and KM participated in the field study and acquired data. All the authors were involved in analysis and interpretation of the data. KO drafted the article; RS, MF, TW and KM revised it critically for important intellectual content; all the authors approved the final version. $\mathrm{KO}$ is guarantor.

Funding The study was funded by the High Altitude Project (leader: KO) in the Research Institute for Humanity and Nature, Kyoto, Japan (D-03, Human Life, Aging and Disease in High-Altitude Environments: Physio-Medical, Ecological and Cultural Adaptation in 'Highland Civilisations'), from Ministry of Education, Culture, Sports, Science and Technology.

Disclaimer No sponsor participated in the design of the study or in the collection, analysis or interpretation of the data.

Competing interests None declared.

Patient consent Obtained.

Ethics approval The study protocol was approved by the institutional review board of Research Institute for Humanity and Nature, Kyoto, Japan (RIHN-2007-02

Provenance and peer review Not commissioned; externally peer reviewed.

Data sharing statement No additional data are available.

Open Access This is an Open Access article distributed in accordance with the Creative Commons Attribution Non Commercial (CC BY-NC 4.0) license, which permits others to distribute, remix, adapt, build upon this work noncommercially, and license their derivative works on different terms, provided the original work is properly cited and the use is non-commercial. See: http:// creativecommons.org/licenses/by-nc/4.0/

\section{REFERENCES}

1. Aldenderfer MS. Moving up in the world. Archaeologists seek to understand how and when people came to occupy the Andean and Tibetan plateaus. Am Sci 2003;91:542-9.

2. Pawson IG, Jest $C$. The high-altitude areas of the world and their cultures. In: Baker PT, ed. The biology of high altitude peoples. New York, NY: Cambridge University Press, 1978:17-45.

3. West JB, Schoene RB, Luks AM, Milledge JS (eds). Geography and the human response to altitude. In: High altitude medicine and physiology. New York, NY: CRC Press, 2013:28-39.

4. Chen $\mathrm{W}$, Liu $\mathrm{Q}$, Wang $\mathrm{H}$, et al. Prevalence and risk factors of chronic kidney disease: a population study in the Tibetan population. Nephrol Transplant 2011;26:1592-9.

5. Santos JL, Pérez-Bravo F, Carrasco E, et al. Low prevalence of type 2 diabetes despite a high average body mass index in the Aymara natives from Chile. Nutrition 2001:17:305-9.

6. Chen F, Yang W, Weng J, et al. Albuminuria: prevalence, associated risk factors and relationship with cardiovascular disease. J Diabetes Invest 2014;5:464-71.

7. Jia W, Gao X, Pang C, et al. Prevalence and risk factors of albuminuria and chronic kidney disease in Chinese population with type 2 diabetes and impaired glucose regulation: Shanghai diabetic complications study (SHDCS). Nephrol Dial Transplant 2009;24:3724-31.

8. Schulz LO, Bennett PH, Ravussin E, et al. Effects of traditional and western environments on prevalence of type 2 diabetes in Pima Indians in Mexico and the U.S. Diabetes Care 2006;29:1866-71.

9. Centers for Disease Control and Prevention (CDC). Prevalence of diagnosed diabetes among American Indians/Alaskan NativesUnited States, 1996. MMWR Morb Mortal Wkly Rep 1998;47:901-4.

10. IDF Diabetes atlas. http://www.diabetesatlas.org/ (accessed 20 May 2015).

11. Wild S, Roglic G, Green A, et al. Global prevalence of diabetes: estimates for the year 2000 and projections for 2030. Diabetes Care 2004;27:1047-53.

12. Lefe'bvre $P$, Silink M. Diabetes fights for recognition. Lancet 2006;368:1625-6.

13. Okumiya $\mathrm{K}$, Ishine $\mathrm{M}$, Wada $\mathrm{T}$, et al. The close association between low economic status and glucose intolerance in the elderly in a rural area in Laos. J Am Geriatr Soc 2007;55:2101-2.

14. Okumiya $\mathrm{K}$, Sakamoto R, Kimura $\mathrm{Y}$, et al. J curve association between economic status and diabetes independently of functional disability in Japanese elderly. Geriatr Gerontol Int 2012;12:755-6.

15. Ravelli AC, van der Meulen JH, Michels RP, et al. Glucose tolerance in adults after prenatal exposure to famine. Lancet 1998;351:173-7. 
16. Whincup PH, Kaye SJ, Owen CG, et al. Birth weight and risk of type 2 diabetes: a systemic review. JAMA 2008;300:2886-97.

17. Gillberg L, Ling C. The potential use of DNA methylation biomarkers to identify risk and progression of type 2 diabetes. Front Endocrinol (Lausanne) 2015;6:43

18. Ling C, Groop L. Epigenetics: a molecular link between environmental factors and type 2 diabetes. Diabetes 2009;58:2718-25.

19. Peacock AJ. ABC of oxygen: oxygen at high altitude. BMJ 1998;317:1063-6.

20. Beall CM. Andean, Tibetan, and Ethiopian patterns of adaptation to high-altitude hypoxia. Integr Comp Biol 2006;46:18-24.

21. Beall CM. Two routes to functional adaptation: Tibetan and Andean high-altitude natives. Proc Natl Acad Sci USA 2007;104(Suppl 1):8655-60.

22. Sahota IS, Panwar NS. Prevalence of chronic mountain sickness in high altitude districts of Himachal Pradesh. Indian J Occup Environ Med 2013;17:94-100.

23. León-Velarde F, Arregui A, Monge CC, et al. Ageing at high altitude and the risk of chronic mountain sickness. $J$ Wilderness Med 1993;4:183-8.

24. León-Velarde F, Arregui A, Vargas M, et al. Chronic mountain sickness and chronic lower respiratory tract disorders. Chest 1994;106:151-5.

25. León-Velarde F, Ramos MA, Hernández JA, et al. The role of menopause in the development of chronic mountain sickness. Am J Physiol 1997;272:R90-4.

26. Rivera Ch M, León-Velarde F, Huicho L. Treatment of chronic mountain sickness: critical reappraisal of an old problem. Respir Physiol Neurobiol 2007;158:251-65.

27. Singh DL, Bhattarai MD. High prevalence of diabetes and impaired fasting glycaemia in urban Nepal. Diabet Med 2003;20:170-1.

28. Sasaki H, Kawasaki T, Ogaki T, et al. The prevalence of diabetes mellitus and impaired fasting glucose/glycaemia (IFG) in suburban and rural Nepal-the communities-based cross-sectional study during the democratic movements in 1990. Diabetes Res Clin Pract 2005;67:167-74.

29. Carrasco EP, Pérez FB, Angel BB, et al. [Prevalence of type 2 diabetes and obesity in two Chilean aboriginal populations living in urban zones]. Rev Med Chil 2004;132:1189-97.

30. Okumiya K, Sakamoto R, Kimura Y, et al. Diabetes mellitus and hypertension in elderly highlanders in Asia. J Am Geriatr Soc 2010;58:1193-5.

31. Sherpa LY, Deji Stigum H, Chongsuvivatwong V, et al. Prevalence of metabolic syndrome and common metabolic components in high altitude farmers and herdsmen at $3700 \mathrm{~m}$ in Tibet. High Alt Med Biol 2013;14:37-44.

32. Baracco R, Mohanna S, Seclén S. A comparison of the prevalence of metabolic syndrome and its components in high and low altitude populations in Peru. Metab Syndr Relat Disord 2007;5:55-62.

33. Norboo T, Stobdan T, Tsering N, et al. Prevalence of hypertension at high altitude: cross-sectional survey in Ladakh, Northern India 2007-2011. BMJ Open 2015;5:e007026.

34. Sun SF. Epidemiology of hypertension on the Tibetan Plateua. Hum Biol 1986;58:507-15.

35. Hu YS, Yao CH, Wang WZ, et al. [Survey on the prevalence of hypertension in different ethnic groups in China in 2002]. Wei Sheng Yan Jiu 2006;35:573-5.

36. Tripathy V, Gupta R. Blood pressure variation among Tibetans at different altitudes. Ann Hum Biol 2007;34:470-83.

37. Lhamo SY, Supamai S, Virasakdi C. Impaired glucose regulation in a Sherpa indigenous population living in the Everest region of Nepa and in Kathmandu Valley. High Alt Med Biol 2008;9:217-22.

38. Woolcott OO, Castillo OA, Gutierrez C, et al. Inverse association between diabetes and altitude: a cross-sectional study in the adult population of the United States. Obesity (Silver Spring) 2014;22:2080-90.

39. Hessien M. Improved glycemic control in moderate altitude type II diabetic residents. High Alt Med Biol 2013;14:27-30.

40. Okumiya K, Sakamoto R, Kimura Y, et al. Strong association between polycythemia and glucose intolerance in elderly high-altitude dwellers in Asia. J Am Geriatr Soc 2010;58:609-11.

41. Popular Government of Haibei Province. Annual report of Health Office in Haibei Province in China, 2008.

42. Popular Government of Haiyan county. Homepage of introduction of Haiyan county. 2008. http://www.qh.xinhuanet.com/haiyan/index.htm (accessed 7 Nov 2008).

43. Editorial committee of History of Haiyan County. History of Haiyan County (Hai An Xian Zhi). Shanghai: Shanghai Academy of Socia Sciences Publisher, 1997.

44. Popular Government of Yushu Province. Annual report of Health Office in Yushu Province in China, 2011.
45. Popular Government of Yushu County. Homepage of introduction of Haiyan county. 2009. http://www.qh.xinhuanet.com/yushu/index.htm (accessed 4 Oct 2009).

46. Zang YS, Zhi ZZ, Zhi Z. History of Yushu Tibetan Autonomous Prefecture. Xian, China: Three Qin Publisher, 2005.

47. Yamaguchi T, Ngodup S, Nose M, et al. Land use and its transition in an agro-silvo-pastoral system of a Ladkhi Village, Jammu \& Kashmir, India. Himalayan study monographs. 2014 (in Japanese) http://www.kyoto-bhutan.org/pdf/Himalayan/014/Himalayan-14-102. pdf14 1-2-113 (accessed 7 May 2015)

48. Okumiya K, Matsubayashi K, Wada T, et al. A U-shaped association between home systolic blood pressure and four-year mortality in community-dwelling older men. J Am Geriatr Soc 1999;47: $1415-121$

49. Chobanian AV, Bakris GL, Black HR, et al. Seventh report of the Joint National Committee on Prevention, Detection, Evaluation, and Treatment of High Blood Pressure. Hypertension 2003;42:1206-52.

50. Karon BS, Griesmann L, Scott R, et al. Evaluation of the impact of hematocrit and other interference on the accuracy of hospital-based glucose meters. Diabetes Technol Ther 2008;10:111-20.

51. Karon BS, Blanshan CT, Deobald GR, et al. Retrospective evaluation of the accuracy of Roche AccuChek Inform and Nova StatStrip glucose meters when used on critically ill patients. Diabetes Technol Ther 2014;16:828-32.

52. Lockyer MG, Fu K, Edwards RM, et al. Evaluation of the Nova StatStrip glucometer in a pediatric hospital setting. Clin Biochem 2014;47:840-3.

53. de Mol P, Krabbe HG, de Vries ST, et al. Accuracy of handheld blood glucose meters at high altitude. PLOS ONE 2010;5:e15485.

54. Olateju T, Begley J, Flanagan D, et al. Effects of simulated altitude on blood glucose meter performance: implications for in-flight blood glucose monitoring. J Diabetes Sci Technol 2012;6:867-74.

55. van Schenck $H$, Falkensson M, Lundberg B. Evaluation of "HemoCue", a new device for determining haemoglobin. Clin Chem 1986;32:526-9.

56. WHO: Hemoglobin concentrations for the diagnosis of anemia and assessment of severity. Vitamin and mineral nutrition information system. Geneva: World Health Organization (WHO/NMH/NHD/MNM/ 11.1), 2011. http://www.who.int/vmnis/indicators/haemoglobin.pdf (accessed 7 May 2015)

57. WHO. Definition and diagnosis of diabetes mellitus and intermediate hyperglycemia. Report of a WHO/IDF consultation. http://whqlibdoc. who.int/publications/2006/9241594934_eng.pdf (accessed 7 May 2015).

58. Klein OL, Krishnan JA, Glick S, et al. Systemic review of the association between lung function and type 2 diabetes mellitus. Diabet Med 2010;27:977-87.

59. Oltmanns KM, Gehring $\mathrm{H}$, Rudolf $\mathrm{S}$, et al. Hypoxia causes glucose intolerance in humans. Am J Respir Crit Care Med 2004;169:1231-7.

60. Punjabi NM, Shahar E, Redline S, et al, Sleep Heart Health Study Investigators. Sleep-disordered breathing, glucose intolerance, and insulin resistance: the Sleep Heart Health Study. Am J Epidemiol 2004:160:521-30.

61. Rasche K, Keller T, Tautz B, et al. Obstructive sleep apnea and type 2 diabetes. Eur J Med Res 2010;15(Suppl 2):152-6.

62. Yamamoto N, Yamanaka G, Ishizawa K, et al. Insomnia increases insulin resistance and insulin secretion in elderly people. J Am Geriatr Soc 2010;58:801-4.

63. Spiegel K, Knutson K, Leproult R, et al. Sleep loss: a novel risk factor for insulin resistance and type 2 diabetes. $J$ Appl Physiol 2005;99:2008-19.

64. Cheng N, Cai W, Jiang M, et al. Effect of hypoxia on blood glucose, hormones, and insulin receptor functions in newborn calves. Pediatr Res 1997:41:852-6.

65. Fujisawa M, Ishine M, Okumiya $\mathrm{K}$, et al. Trends in diabetes. Lancet 2007;369:1257.

66. Tamariz LJ, Young JH, Pankow JS, et al. Blood viscosity and hematocrit as risk factor for type 2 diabetes mellitus: the atherosclerosis risk in communities (ARIC) study. Am J Epidemiol 2008;168:1153-60.

67. Okumiya $\mathrm{K}$, Sakamoto $\mathrm{R}$, Ishikawa $\mathrm{M}$, et al. The J-curve association between glucose intolerance with hemoglobin and ferritin levels at high-altitude. J Am Geriatr Soc 2016;64:207-10.

68. Kimura Y, Matsubayashi K, Sakamoto R, et al. Food diversity and its relation to health of highlanders-comparison of urban and rural settings in Qinghai and Ladakh. Himalayan Study Monograph 2012;13:86-93. http://www.kyoto-bhutan.org/pdf/Himalayan/013/ Himalayan-13-086.pdf (in Japanese)

69. Beall CM, Cavalleri GL, Deng L, et al. Natural selection on EPAS1 (HIF2alpha) associated with low hemoglobin concentration in Tibetan highlanders. Proc Natl Acad Sci USA 2010;107:11459-64. 
70. Simonson TS, Yang Y, Huff CD, et al. Genetic evidence for high-altitude adaptation in Tibet. Science 2010;329:72-5.

71. Yi X, Liang Y, Huerta-Sanchez E, et al. Sequencing of 50 human exomes reveals adaptation to high altitude. Science 2010;329:75-8.

72. Beall CM. Genetic changes in Tibet. High Alt Med Biol 2012;12:101-2.

73. Simonson TS, McClain DA, Jorde LB. Genetic determinants of Tibetan high-altitude adaptation. Hum Genet 2012;131:527-33.

74. Beall CM, Brittenham GM, Strohl KP. Hemoglobin concentration of high-altitude Tibetans and Bolivian Aymara. Am J Phys Anthropol 1998;106:385-400.

75. Buroker NE, Ning XH, Zhou ZN, et al. EPAS1 and EGLN1 association with high altitude sickness in Han and Tibetan Chinese at the Qinghai-Tibetan Plateau. Blood Cells Mol Dis 2012;49:67-73.

76. Weintrob N, Karp M, Hod M. Short- and long-range complications in offspring of diabetic mothers. J Diabetes Complications 1996;10:294-301.
77. Cetin H, Yalaz M, Akisu M, et al. Polycythaemia in infants of diabetic mothers: $\beta$-hydroxybutyrate stimulates erythropoietic activity. J Int Med Res 2011;39:815-21.

78. Ge RL, Simonson TS, Cooksey RC, et al. Metabolic insight into mechanisms of high-altitude adaptation in Tibetans. Mol Genet Metab 2012;106:244-7.

79. McClain DA, Simonson TS, Cooksey RC, et al. Metabolic consequences of genetic adaptation to high altitude in Tibetans. 2nd Congress of Asia-Pacific Society for Mountain Medicine (APSMM) [abstract]; 2011:11.

80. Sakamoto R, Matsubayashi K, Kimura Y, et al. Comprehensive geriatric assessment of elderly highlanders in Qinghai, China, III: oxidative stress and aging in Tibetan and Han elderly highlanders. Geriatr Gerontol Int 2009;9:352-8.

81. Sakamoto R, Okumiya $\mathrm{K}$, Wang $\mathrm{H}$, et al. Oxidized low density lipoprotein among the elderly in Qinghai-Tibet Plateau. Wilderness Environ Med 2015;26:343-9. 